LCRL-53237

Distribution Category $\mathrm{LC}-7 \mathrm{O}$

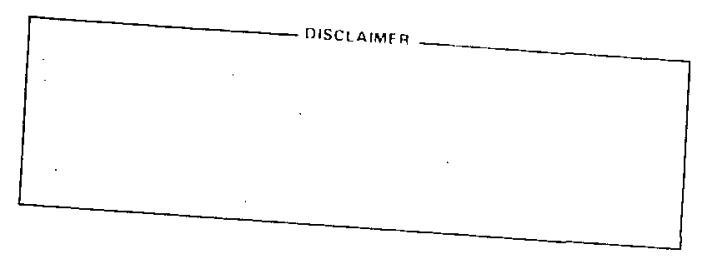

\title{
Formulation of SYNROC-D Additives for Savannah River Plant High-Level Radioactive Waste
}

\author{
F. J. Ryerson \\ K. Burr \\ R. Rozsa
}

Manuscript date: November 1981
ICIT -53237

2012 912405

\section{MOTICE}

PORTIONS OF THIS REPORT ARE ILLEGIDLE

it has been reproduced from the best auallable copy to permit the broadest

posstble avallability.

\section{LAWRENCE LIVERMORE LABORATORY University of California - Livermore, California 94550}




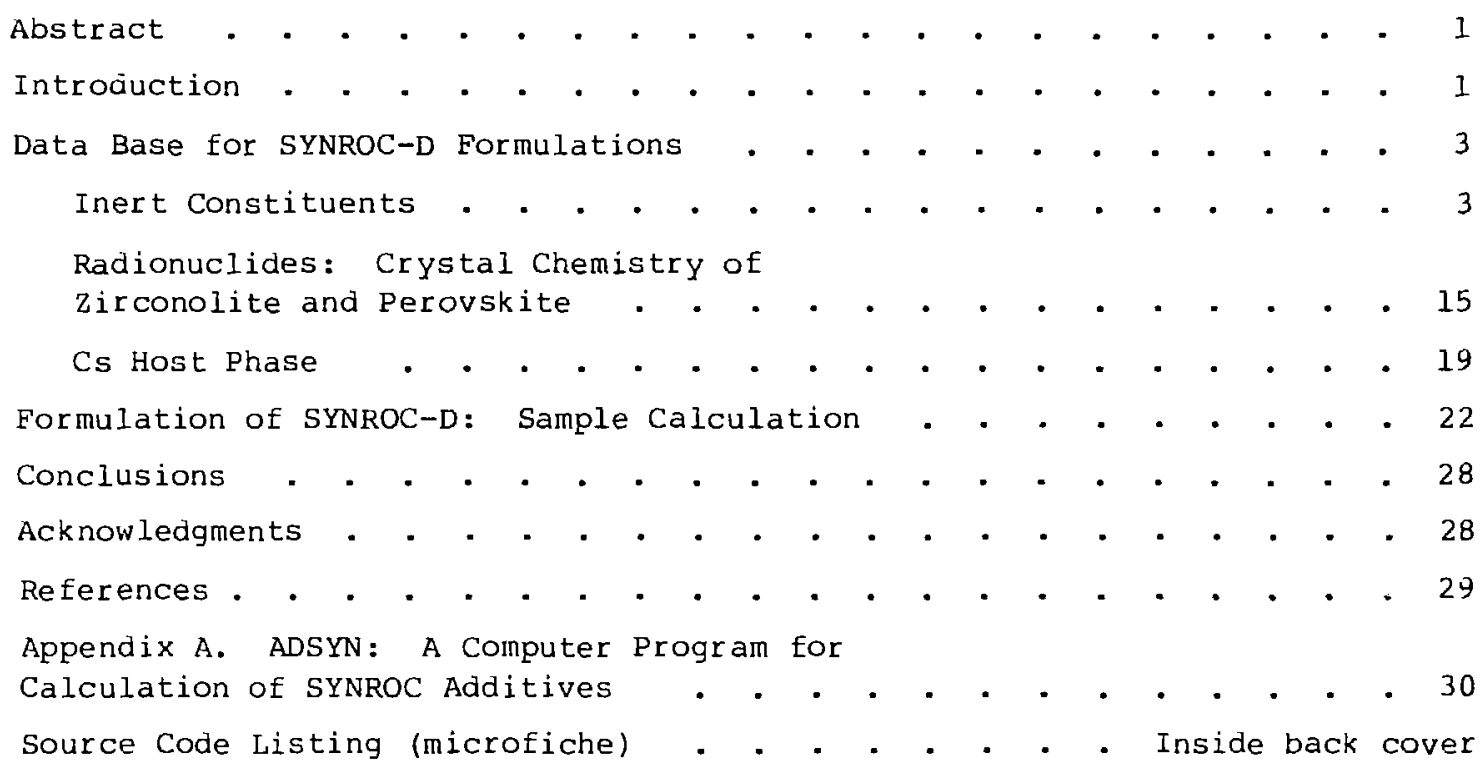


FORMULATION OF SYNROC-D

ADDITIVES FOR SAVANNAH RIVER PLANT

HIGH-LEVEL RADIOACTIVE WASTE

\section{ABSTRACT}

SYNROC-D is a multiphase ceramic waste form consisting of nepheline, zirsonolite, perovskite, and spinel. It has been formulated for the immobilization of high-level radioactive wastes now stored at the Savannah River Plant (SRP) near Aiken, South Carolina. This report utilizes existing experimental data to develop a method for calculating additives to these waste products. This method calculates additions based on variations of mineral compositions as a function of sludge composition and radionuclide partitioning among the SYNROC phases. Based on these calculations, a FORTRAN program called ADSYN has been developed to determine the proper reagent proportions to be added to the SRP sludges.

\section{INTRODUCTION}

SYNROC-D is a multiphase titanate-silicate ceramic designed to immobilize the radionuclides and processing contaminants contained in the hydroxide sludges and supernate solutions currently stored at DuPont's Savannah River Plant (SRP) near Aiken, South Carolina. The SYNROC-D phase assemblage consists of five major mineral phases: zirconolite $\left(\mathrm{CazrTi}_{2} \mathrm{O}_{7}\right)$, perovskite $\left(\mathrm{CaTiO}_{3}\right)$, spinel $\left(\mathrm{MN}_{2} \mathrm{O}_{4}-\mathrm{M}_{2} \mathrm{TO}_{4}, \mathrm{M}=\right.$ divalent cation, $\mathrm{N}=$ trivalent cation, $\mathrm{T}$ = tetravalent cation), and nepheline ( $\left.\operatorname{NaAlsiO}_{4}\right)$. Minor sulfide, pollucite (CsAlsi ${ }_{2} \mathrm{O}_{6}$ ), and phosphate phases may also be present.

The sludges at SRP are chemically complex and variable. They contain the full complement of actinides, lanthanides, alkalis, and alkaline earths found in commercial reactor wastes (see Table 1, after stone et al., 1979). However, their chemistry is dominated by inert processing contaminants including transition metals Ni, Fe, Mn, Cr, alumina, silica, and $\mathrm{Na}$ (see Table 2, after Stone et al., 1979). The High-Fe and High-Al are extreme end-member compositions, while the composite is the estimated average composition of all SRP sludges. 
Table 1. Major components in simulated SRP waste calcines (after stone et al., 1979).

\begin{tabular}{lrrr}
\hline Component & High-Fe & Composite & High-Al \\
\hline $\mathrm{Fe}_{2} \mathrm{O}_{3}$ & 53.17 & 36.13 & 5.32 \\
$\mathrm{Al}_{2} \mathrm{O}_{3}$ & 4.89 & 28.26 & 76.05 \\
$\mathrm{MnO}_{2}$ & 3.56 & 9.94 & 4.37 \\
$\mathrm{U}_{3} \mathrm{O}_{8}$ & 12.34 & 3.26 & 1.28 \\
$\mathrm{CaO}$ & 3.62 & 2.69 & 1.28 \\
$\mathrm{NiO}$ & 9.08 & 4.47 & 0.78 \\
$\mathrm{SiO}_{2}$ & 0.40 & 0.85 & 0.56 \\
$\mathrm{Na}_{2} \mathrm{O}$ & 4.52 & 5.08 & 1.96 \\
$\mathrm{Na}_{2} \mathrm{O}^{2}$ & 4.52 & 5.08 & 1.96 \\
$\mathrm{Na}_{2} \mathrm{SO}_{4}$ & $<0.50$ & 0.93 & $<0.50$ \\
Ion-Siv IE-95 $^{\mathrm{a}}$ & 8.82 & 8.93 & 9.33 \\
\hline
\end{tabular}

a Mixture of $\mathrm{CaAl}_{2} \mathrm{Si}_{4} \mathrm{O}_{12} \cdot 6 \mathrm{H}_{2} \mathrm{O}$ and (NaRCa) ${ }_{3} \mathrm{Al}_{3} \mathrm{SiO}_{24} \cdot 8 \mathrm{H}_{2} \mathrm{O}$.

SYNROC-D is capable of incorporating all these elements as components in solid solution in the phases described above. To produce the SYNROC-D phase assemblage, the tailoring additives $\mathrm{CaO}, \mathrm{SiO}_{2}, \mathrm{ZrO}_{2}, \mathrm{TiO}_{2}$ and, in some cases, $\mathrm{Al}_{2} \mathrm{O}_{3}$ or $\mathrm{Fe}_{2} \mathrm{O}_{3}$ must be added to the sludges in prescribed amounts. In theory, the process of formulating additives consists simply of altering bulk composition such that the composition enters the desired phase volume. The phase volume is an n-dimensional polyhedron in compositional space, whose apices are defined by the compositions of the coexisting sYNROC phases. This is schematically displayed in Fig. 1 where $S$ is the sludge composition and SA is the final composition (sludge plus additives) lying within the sYNROC phase volume. The direction of vector S-SA is determined by the proportions of the different additive components, and its magnitude is determined by their amount. The magnitude of $\mathrm{S}-\mathrm{SA}$ is inversely proportional to the waste loading (weight of sludge/weight of sludge plus additives). In practice, the additive formulation must: 1$)$ produce the desired phase assemblage; 2) maximize the waste loading; and 3) minimize the risk due to credible error.

This report presents the method by which SYNROC additives have been calculated for development at LLNL. Also included is a FORTRAN program, 
Table 2. Minor components in SRP waste sludges (Stone et $21 ., 1979$ ).

\begin{tabular}{llll}
\hline Element & Range (wt) & Element & Range (wt) \\
\hline $\mathrm{C}$ & $0-16.8$ & $\mathrm{Nb}$ & $0.02-0.1$ \\
$\mathrm{Nd}$ & $0.3-1.0$ & $\mathrm{Hg}$ & $0.1-2.8$ \\
$\mathrm{Zr}$ & $0.1-0.5$ & $\mathrm{Y}$ & $0.01-0.05$ \\
$\mathrm{Cr}$ & $0.01-0.45$ & $\mathrm{Ag}$ & $0-0.3$ \\
$\mathrm{Ru}$ & $0.03-0.5$ & $\mathrm{Fm}$ & $0-0.04$ \\
$\mathrm{Ba}$ & $0.1-0.25$ & $\mathrm{~Pb}$ & $0.1-0.5$ \\
$\mathrm{Ce}$ & $0.05-1.0$ & $\mathrm{Ti}$ & $0-0.1$ \\
$\mathrm{~K}$ & $0.02-0.14$ & $\mathrm{Sm}$ & $0-0.05$ \\
$\mathrm{Cl}$ & $0-2.0$ & $\mathrm{Eu}$ & $0-0.02$ \\
$\mathrm{Sr}$ & $0-0.15$ & $\mathrm{~V}$ & $0-0.01$ \\
$\mathrm{La}$ & $0.04-0.3$ & $\mathrm{Rh}$ & $0-0.05$ \\
$\mathrm{~S}$ & $0.02-0.5$ & $\mathrm{~F}$ & $0-0.15$ \\
$\mathrm{P}$ & $0.03-0.3$ & $\mathrm{Cs}$ & $0-0.06$ \\
$\mathrm{Zn}$ & $0.04-0.5$ & $\mathrm{Cd}$ & $0-0.05$ \\
$\mathrm{Th}$ & $0-0.18$ & $\mathrm{Pd}$ & $0-0.03$ \\
$\mathrm{Mg}$ & $0.09-0.3$ & $\mathrm{Mo}$ & $0-0.01$ \\
$\mathrm{Cu}$ & $0.03-0.15$ & $\mathrm{Eu}$ & $0-0.01$ \\
& & $\mathrm{Co}$ & $0-0.01$ \\
\hline
\end{tabular}

ADSYN, * that calculates additive components and reagents as a function of sludge composition. Also outlined are areas where improved experimental data are required for better modeling.

DATA BASE FOR SYNROC-D FORMULATIONS

INERT CONSTITUENTS

The SRP sludges are composed primarily of inert processing contaminants. Due to their predominance, these species play a major role in determining the

* See ADSYN Source code microfiche, inside back cover. 


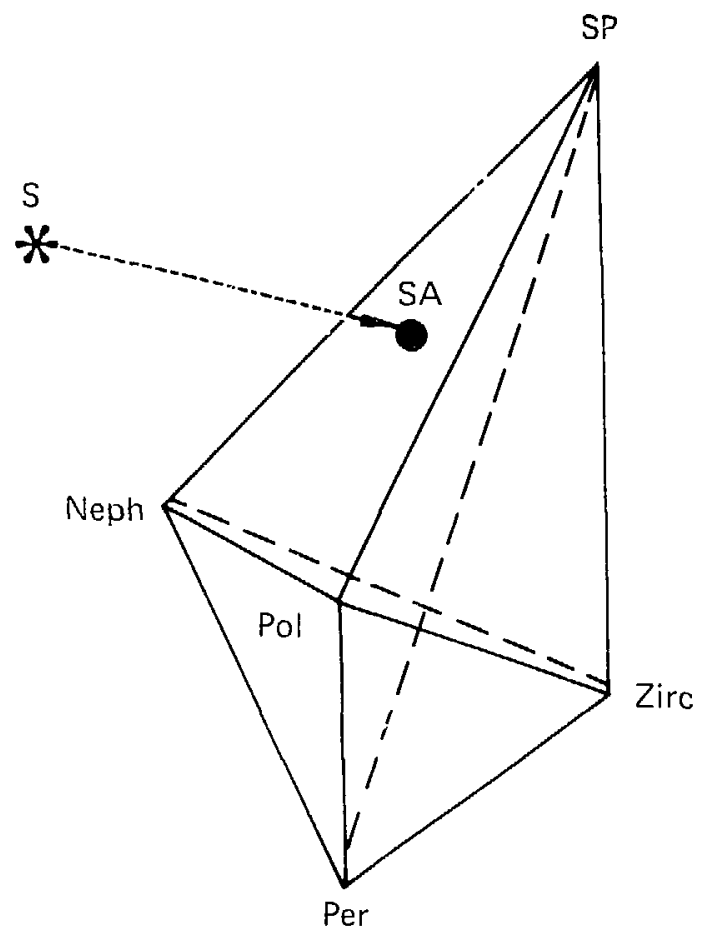

Figure 1. Schematic of tailoring additives for SYNROC-D. The final SYNROC-D phase assemblage is represented by the n-dimensional polyhedron SP-NEPH-ZIRC-PER-POL, the apices of which represent the compositions of the mineral phases.

mineralogy and modal abundances in any SYNROC-D assemblage. The immobilization of these components is, therefore, the most immediate consideration. As shown in Fig. 1, proper formulation of SYNROC additives depends on the relative position of the sludge and SYNROC phase volume in compositional space. The problem is trivial in a case where the starting composition is known and the phase volume apices are fixed in compositional space (i.e., the SYNROC phases show no compositional variability). This, of course, is not the case in SYNROC-D.

In SYNROC-D, the compositions of coexisting phases change as a result of synthesis conditions, sludge composition, and the proportions of additive components. Ideally, the calculation of additives should employ an iterative approach. In this manner, mineral compositions are first determined on the basis of sludge composition and the additives are calculated. On the basis of sisese additives, the mineral compositions are then refined and the additives $\equiv: \equiv$ ajjusted. This process continues until convergence is reached. Such an $\equiv 50$ rəach requires a detailed understanding of how mineral compositions are $=i \equiv=\equiv j$ to bulk composition and synthesis conditions. At this time, however, $r$ : zis jatailed data are available. A simpler technique has, therefore, been $\because n:$ This technique assumes that the compositions of some phases 
(zirconolite and perovskite) remain constant over the specified ranges of SRP sludge compositions (High-Fe, composite, and High-Al).

The mineral compositions used in our calculations are derived from the work of Ringwood et al. (1979). In these experiments, simulated sludge calcines approximating the compositions of the SRP High-Al, High-Fe, and composite sludges (Table 3 ! were combined with $\mathrm{TiO}_{2}, \mathrm{ZrO}_{2}, \mathrm{CaO}, \mathrm{SiO}_{2}$, and $\mathrm{Al}_{2} \mathrm{O}_{3}$ and pressed in Pt capsules in a solid-medium pressure apparatus. Run conditions were $1200^{\circ} \mathrm{C}$ at $500 \mathrm{MPa}$, and the $\mathrm{O}$ fugacity was close to that of the Ni-Ni oxide buffer. The additives in successive experiments were adjusted until only the desired phases (zirconolite, perovskite, nepheline, and spinel) were formed. The compositions of the coexisting phases were determined and combined in the approximate wt ratios, 1:1:4:1; zir: per: sp: neph. These ratios maximize the loading while still allowing dilute solution of radionuclides in zirconolite and perovskite. The necessary additives were calcuiated from the final bulk composition.

Inspection of coexisting mineral compositions (Table 4 ) reveals some interesting features. The compositions of the phases, zirconolite, perovskite, and nepheline, are relatively constant in the three formulations, and they plot close to the ideal mineral compositions (Figs. 2 and 3 ).

Table 3. Simulated sludge compositions plus additives.

\begin{tabular}{|c|c|c|c|c|c|c|c|c|c|}
\hline & \multicolumn{3}{|c|}{ High-Al } & \multicolumn{3}{|c|}{ High-Fe } & \multicolumn{3}{|c|}{$\mathrm{High}-\mathrm{Fe}$} \\
\hline & $\begin{array}{l}\text { Calcined } \\
\text { sludge }\end{array}$ & $\begin{array}{l}\text { Addi- } \\
\text { tives }\end{array}$ & Total & $\begin{array}{l}\text { Calcined } \\
\text { sludge }\end{array}$ & $\begin{array}{l}\text { Addi- } \\
\text { tives }\end{array}$ & Total & $\begin{array}{l}\text { Calcined } \\
\text { sludge }\end{array}$ & $\begin{array}{l}\text { Addi- } \\
\text { tives }\end{array}$ & Total \\
\hline $\mathrm{SiO}_{2}$ & - & 6.5 & 6.5 & 1.4 & 4.8 & 6.2 & 1.6 & 7.5 & 8.1 \\
\hline $\mathrm{TiO}_{2}$ & - & 16.7 & 16.7 & -- & 16.8 & 16.8 & -- & 15.0 & 15.0 \\
\hline $\mathrm{ZrO}_{2}$ & -- & 4.2 & 4.2 & - & 4.0 & 4.0 & - & 4.0 & 4.0 \\
\hline $\mathrm{UO}_{2}$ & 2.3 & -- & 2.3 & 2.4 & -- & 2.4 & 2.3 & - & 2.3 \\
\hline $\mathrm{Al}_{2} \mathrm{O}_{3}$ & 33.8 & -- & 33.8 & 3.7 & 5.4 & 9.1 & 21.2 & -- & 21.2 \\
\hline $\mathrm{Pe}_{2} \mathrm{O}_{3}$ & 17.7 & -- & 17.7 & 36.8 & -- & 36.8 & 27.1 & -- & 27.1 \\
\hline Mno & 5.3 & -- & 5.3 & 6.1 & -- & 6.1 & 6.1 & -- & 6.1 \\
\hline NiO & 0.6 & - & 0.6 & 6.6 & -- & 6.6 & 3.4 & -- & 3.4 \\
\hline $\mathrm{CaO}$ & 2.1 & 5.5 & 7.6 & 1.9 & 5.0 & 6.9 & 2.0 & 4.9 & 5.9 \\
\hline $\mathrm{Na}_{2} \mathrm{O}$ & 3.4 & -- & 3.4 & 3.2 & -- & 3.2 & 3.8 & -- & 3.8 \\
\hline${ }^{F_{p^{\prime}}}{ }^{A^{a}}$ & 2.0 & -- & 2.0 & 2.0 & -- & 2.0 & 2.1 & -- & 2.1 \\
\hline TOTAL & 67.0 & 33.0 & 100.0 & 64.0 & 36.0 & 100.0 & 69.0 & 31.0 & 100.0 \\
\hline
\end{tabular}

${ }^{a}{ }_{p}, A=$ Fission product plus actinides. 
Table $4 a$. Compositions of coexisting phases (High-Fe).

\begin{tabular}{|c|c|c|c|c|}
\hline A. wtq oxides & Zirconolite & Perovskite & Spinel & Nepheline \\
\hline $\mathrm{SiO}_{2}$ & -- & -- & -- & 40.6 \\
\hline $\mathrm{TiO}_{2}$ & 35.1 & 52.4 & 7.9 & 0.5 \\
\hline $\mathrm{ZiO}_{2}$ & 25.2 & 1.4 & -- & -- \\
\hline $\mathrm{UO}_{2}$ & 15.5 & 2.6 & -- & - \\
\hline $\mathrm{Al}_{2} \mathrm{O}_{3}$ & 0.4 & 1.5 & 8.1 & 34.4 \\
\hline $\mathrm{Fe}_{2} \mathrm{O}_{3}$ & 7.8 & 1.6 & 43.5 & 5.0 \\
\hline $\mathrm{FeO}$ & -- & -- & 20.7 & - \\
\hline Mno & 1.8 & 0.8 & 9.0 & -- \\
\hline NiO & -- & 0.2 & 9.7 & -- \\
\hline $\mathrm{CaO}$ & 14.6 & 39.8 & -- & -- \\
\hline $\mathrm{Na}_{2} \mathrm{O}$ & 0.2 & -- & -- & 20.1 \\
\hline Total & 100.6 & 100.3 & 98.9 & 100.7 \\
\hline \multicolumn{5}{|c|}{ B. Atoms/formula unit } \\
\hline $\mathrm{Si}$ & -- & -- & -- & 1.10 \\
\hline $\mathrm{Ti}$ & 1.66 & 0.91 & 0.22 & 0.01 \\
\hline $\mathrm{zr}$ & 0.78 & 0.02 & -- & -- \\
\hline $\mathrm{U}$ & 0.22 & 0.01 & -- & -- \\
\hline Al & 0.03 & 0.04 & 0.35 & 1.10 \\
\hline $\mathrm{Fe}^{3+}$ & 0.37 & 0.03 & 1.21 & 0.10 \\
\hline $\mathrm{Fe}^{2+}$ & - & -- & 0.64 & - \\
\hline Mn & 0.09 & 0.02 & 0.28 & -- \\
\hline $\mathrm{Ni}$ & - & 0.02 & 0.29 & -- \\
\hline $\mathrm{Ca}$ & 0.99 & 0.99 & - & -- \\
\hline $\mathrm{Na}$ & - & - & -- & 1.06 \\
\hline Total cations & 4.14 & 2.03 & 3.00 & 3.37 \\
\hline $\begin{array}{l}\text { No. oxygens/ } \\
\text { formula unit }\end{array}$ & 7.00 & 3.00 & 4.00 & 4.00 \\
\hline
\end{tabular}


Table 4b. Compositions of coexisting phases (High-Al).

\begin{tabular}{|c|c|c|c|c|}
\hline A. wto oxides & Zirconolite & Perovskite & Spinel & Nepheline \\
\hline $\mathrm{SiO}_{2}$ & - & -- & -- & 41.5 \\
\hline $\mathrm{TiO}_{2}$ & 30.1 & 53.2 & 5.8 & 0.2 \\
\hline $\mathrm{ZiO}_{2}$ & 38.5 & 0.7 & 0.3 & -- \\
\hline $\mathrm{UO}_{2}$ & 14.2 & 4.8 & -- & -- \\
\hline $\mathrm{Al}_{2} \mathrm{O}_{3}$ & 1.1 & 0.3 & 48.3 & 35.9 \\
\hline $\mathrm{FeO}$ & 4.2 & 2.4 & 37.4 & 0.8 \\
\hline $\mathrm{MnO}$ & 0.9 & 0.7 & 7.2 & 0.2 \\
\hline NiO & -- & -- & 0.4 & -- \\
\hline $\mathrm{CaO}$ & 12.5 & 38.1 & -- & - \\
\hline $\mathrm{Na}_{2} \mathrm{O}$ & 0.4 & -- & -- & 21.5 \\
\hline Total & 101.9 & 100.2 & 99.4 & 100.1 \\
\hline \multicolumn{5}{|c|}{ B. Atoms/formula unit } \\
\hline $\mathrm{Si}$ & -- & -- & - & 0.99 \\
\hline $\mathrm{Ti}$ & 1.45 & 0.95 & 0.13 & 0.01 \\
\hline $2 r$ & 1.20 & 0.01 & -- & -- \\
\hline $\mathrm{U}$ & 0.20 & 0.03 & -- & -- \\
\hline Al & 0.08 & 0.01 & 1.73 & 1.00 \\
\hline $\mathrm{Fe}$ & 0.22 & 0.05 & 0.95 & 0.01 \\
\hline Mn & 0.05 & 0.01 & 0.18 & 0.02 \\
\hline $\mathrm{Ni}$ & - & - & 0.01 & $-\infty$ \\
\hline $\mathrm{Ca}$ & 0.86 & 0.97 & -- & -- \\
\hline $\mathrm{Na}$ & 0.05 & -- & -- & 0.99 \\
\hline Total cation & 4.11 & 2.03 & 3.01 & 3.02 \\
\hline $\begin{array}{l}\text { No. oxygens/ } \\
\text { formula unit }\end{array}$ & 7.00 & 3.00 & 4.00 & 4.00 \\
\hline
\end{tabular}


Table 4c. Compositions of coexisting phases (composite).

\begin{tabular}{|c|c|c|c|c|}
\hline A. wts oxides & Zirconolite & Perovskite & Spinel & Nepheline \\
\hline $\mathrm{SiO}_{2}$ & -- & -- & - & 41.0 \\
\hline $\mathrm{TiO}_{2}$ & 32.5 & 53.6 & 14.3 & 0.5 \\
\hline $\mathrm{ZiO}_{2}$ & 32.7 & -- & 0.2 & -- \\
\hline $\mathrm{UO}_{2}$ & 11.2 & 3.0 & 0.1 & -- \\
\hline $\mathrm{Al}_{2} \mathrm{O}_{3}$ & 1.1 & 0.1 & 17.2 & 35.2 \\
\hline $\mathrm{Fe}_{2} \mathrm{O}_{3}$ & 7.1 & 2.7 & 20.5 & 1.1 \\
\hline $\mathrm{Sm}_{2} \mathrm{O}_{3}$ & 2.5 & 6.8 & -- & -- \\
\hline FeO & -- & -- & 31.0 & -- \\
\hline MnO & 0.9 & 0.3 & 10.8 & -- \\
\hline NiO & 2.1 & 0.2 & 5.7 & -- \\
\hline $\mathrm{CaO}$ & 9.8 & 34.1 & 0.2 & 0.8 \\
\hline $\mathrm{Na}_{2} \mathrm{O}$ & 0.7 & 0.5 & - & 21.4 \\
\hline Total & 100.6 & 101.3 & 100.0 & 100.0 \\
\hline \multicolumn{5}{|c|}{ B. Atoms/formula unit- } \\
\hline $\mathrm{si}$ & -- & - & -- & 0.98 \\
\hline $\mathrm{Ti}$ & 1.54 & 0.96 & 0.38 & 0.01 \\
\hline $\mathrm{z}:$ & 1.01 & -- & -- & -- \\
\hline $\mathrm{U}$ & 0.16 & 0.02 & - & - \\
\hline Al & 0.08 & -- & 0.71 & 0.99 \\
\hline $\mathrm{Fe}^{3+}$ & 0.34 & 0.05 & 0.54 & 0.02 \\
\hline $\begin{array}{l}\mathrm{Sm} \\
\mathrm{Fe}^{2+}\end{array}$ & $\begin{array}{r}0.05 \\
--\end{array}$ & $\begin{array}{r}0.05 \\
--\end{array}$ & $0 . \overline{90}$ & - \\
\hline$M n$ & 0.05 & 0.01 & 0.32 & -- \\
\hline $\mathrm{Ni}$ & 0.11 & -- & 0.16 & -- \\
\hline $\mathrm{Ca}$ & 0.67 & 0.87 & - & 0.02 \\
\hline $\mathrm{Na}$ & 0.04 & 0.02 & -- & 0.99 \\
\hline Total cation & 4.05 & 1.98 & 3.01 & 3.01 \\
\hline $\begin{array}{l}\text { No. oxygens/ } \\
\text { formula unit }\end{array}$ & 7.00 & 3.00 & 4.00 & 4.00 \\
\hline
\end{tabular}




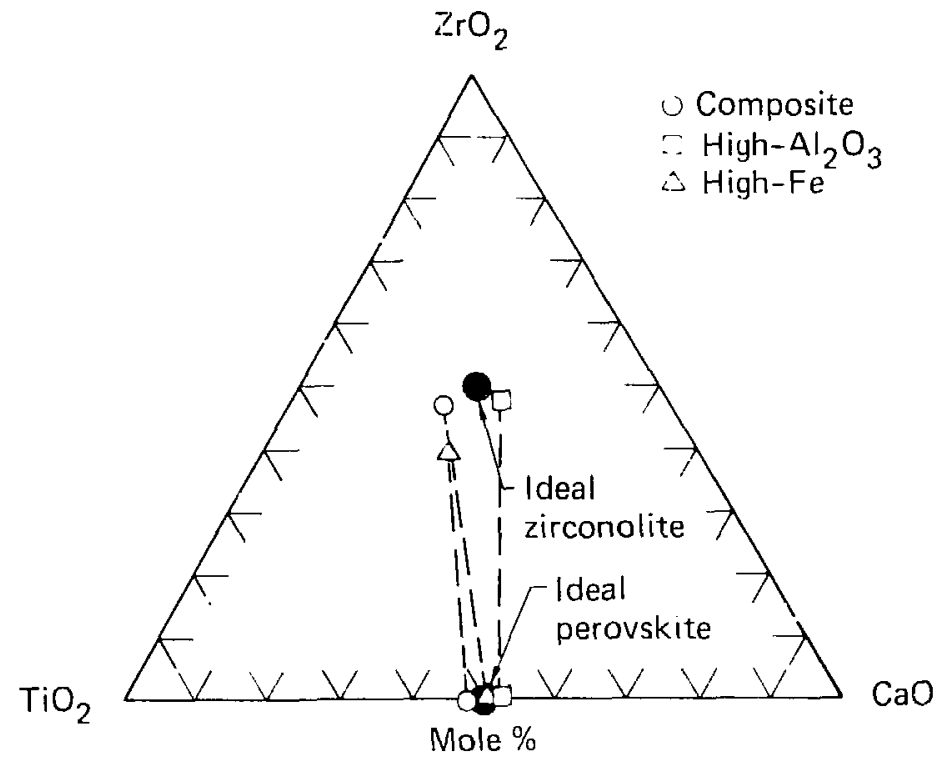

Figure 2. Composition of coexisting perovskites and $\mathrm{zirconolites}$ produced in densified SYNROC-D formulations for High-Al, composite, and High-Fe sludges (after Ringwood et al., 1979). The filled circles represent the ideal mineral stoichiometries, $\mathrm{CaTiO}_{3}$ and $\mathrm{CaZrTi}_{2} \mathrm{O}_{7}$. The data indicate that the departure from ideal formulas is relatively small. Hence, the sludge components act essentially as dilutants and do not strongly alter the relative activity coefficients of $\mathrm{CaO}, \mathrm{ZrO}_{2}$, and $\mathrm{TiO}_{2}$ in these phases.

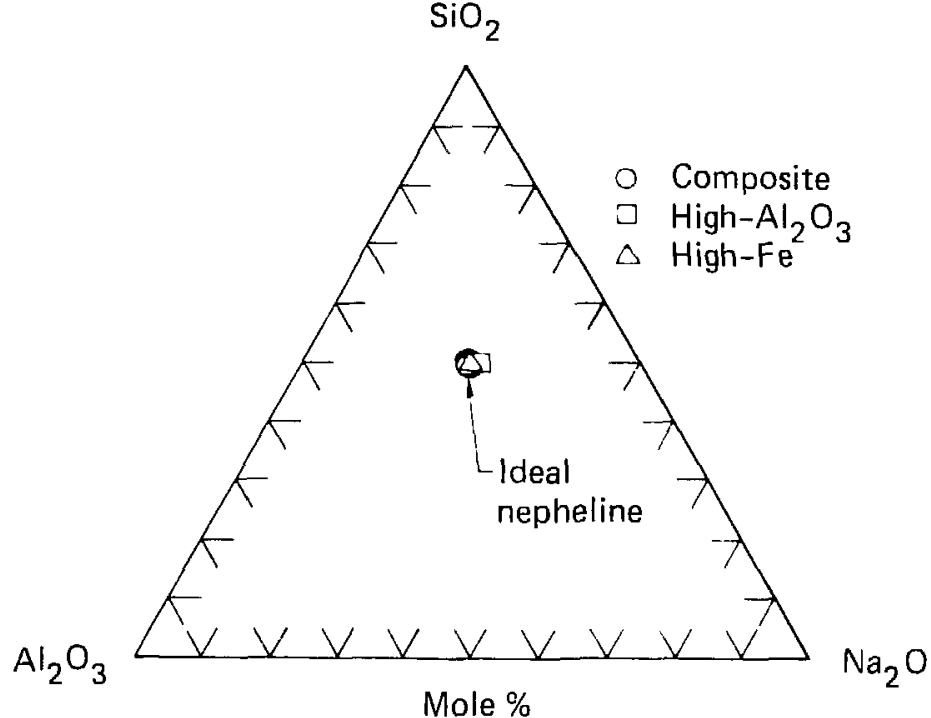

Figure 3. Compositions of rephelines produced in densified SYNROC-D assemblages for High-Al, composite, and High-Fe sludges. The ideal stoichiometry NaAlsio 4 (fitted circle) compares favorably with those from SYNROC-D. 


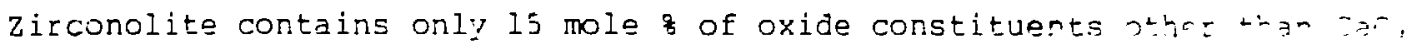
$\mathrm{ZrO}_{2}$, and $\mathrm{TiO}_{2}$. The additional constituents of i.mportance $=\cdots, \mathrm{Y}$,

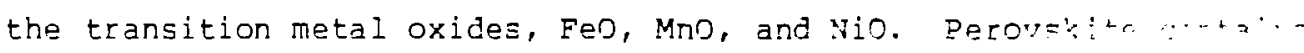

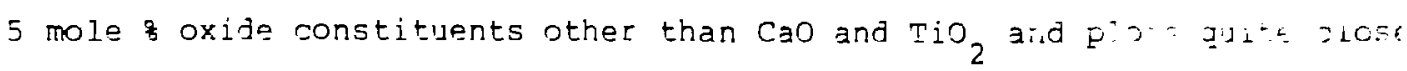
the ideal composition. As in zieconolite, $0_{2}$ and the tar. . . ibr Just oxides constitute the remainder of the perovs'ite. The caes 15 ayer more extreme for nepheline, which contains a maximum of 2 mole $7 . \ldots \ldots$ other than $\mathrm{Na}_{2} \mathrm{O}, \mathrm{Al}_{2} \mathrm{O}_{3}$, and $\mathrm{SiO}_{2}$.

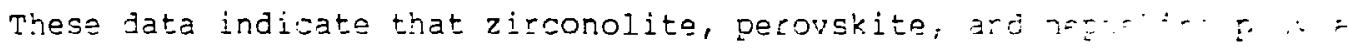
xinor role in the incorporation of the inert components ri fis 2 ? - " Jy (with the exception 0 . va in repheline). The compositions of thase freste. therefore, show little variation as a function of sludge compoitio. Iformilating the additives 7ecessary to produce these phases, axpe : -ar:

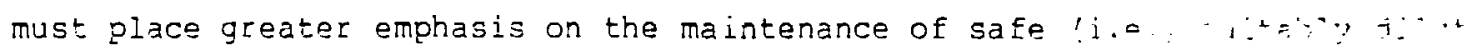
radionuciide ioading levels, rather than the effects of inert onop... variztions. For instance, if the concentrations of inert compononts ir zirconolite and perovskite are completely neglected, an ercor of oni $z$ irrie is incurrod in furmilating additives.

Large compositional variations in spp sludge are not reflected in the compositions of perovskite, nepheline, and zirconolite. This ieares an:: spinel to incorporate compositional fluctuations in the sludges itable 4. As Euch, the compositional variations in the sludges must be refiected in that of the spinels. The relationship between sludge compcrents and spiriel compositions is shown in Fig. 4. The High-Al sludge is characterized by high $\mathrm{Al}_{2} \mathrm{O}_{3}$ content, producing hercynitic (FeAl $\mathrm{O}_{4}$ ) spinels. The fijah-Fe sludge is characterized by high $\mathrm{Fe}_{2} \mathrm{O}_{3}$ contents, which produce ierrite $\left(\mathrm{M}^{2+} \mathrm{Fe}_{2} \mathrm{O}_{4}\right)$ spinels. These tipes of spinels contain relatively litt $a$ the $\mathrm{TiO}_{2}$ ajditive compared to the more complex spinels in the composise sludge (Fig. 5). The composite spinel is a solid solution of 25.8 role magnetite, 35.3 mole hercynite, and 37.9 moles ulyöspinel components $\left(\mathrm{M}_{2} \mathrm{TiO}_{4}\right)$. The large ulvöspinel component in the composite spinel illustrates that a certain amount of $\mathrm{TiO}_{2}$ mist be allxated to these spireis when additives are formulated. The amount of $\mathrm{TiO}_{2}$ varies with $\mathrm{Fe} /(\mathrm{Fe}+\mathrm{Al}$ in both the spinel and (since the spinel reflects the ororall bulk corr sait: on the sludge (Fig. 5). The Tio, content reaches a maximum at the composits formulation. This trend in $\mathrm{TiO}_{2}$ content mimics that of the variabie, 


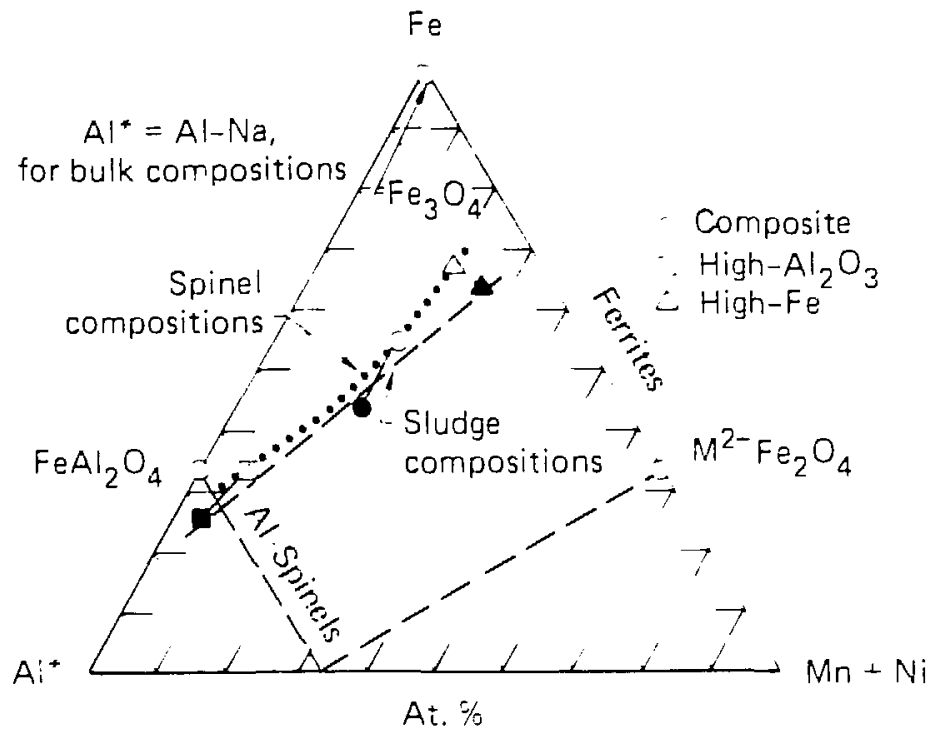

Figure 4. Comparison of spinels in densified SYNROC-D for High-Fe, conposite, and High-Al formulations, and the initial sludge compositions. The data are plotted in terms of atomic proportions of $\mathrm{Fe}, \mathrm{Mn}+\mathrm{Ni}$, and $\mathrm{Al}$ * (= Al - Na to account for A.I accomodated in nepheline). O is not plotted in the diagram, hence $\mathrm{Fe}_{3} \mathrm{O}_{4}$ plots at $\mathrm{Fe}$. Sluoge compositions are shown by filled symbols, spinel composition by open symbols. 

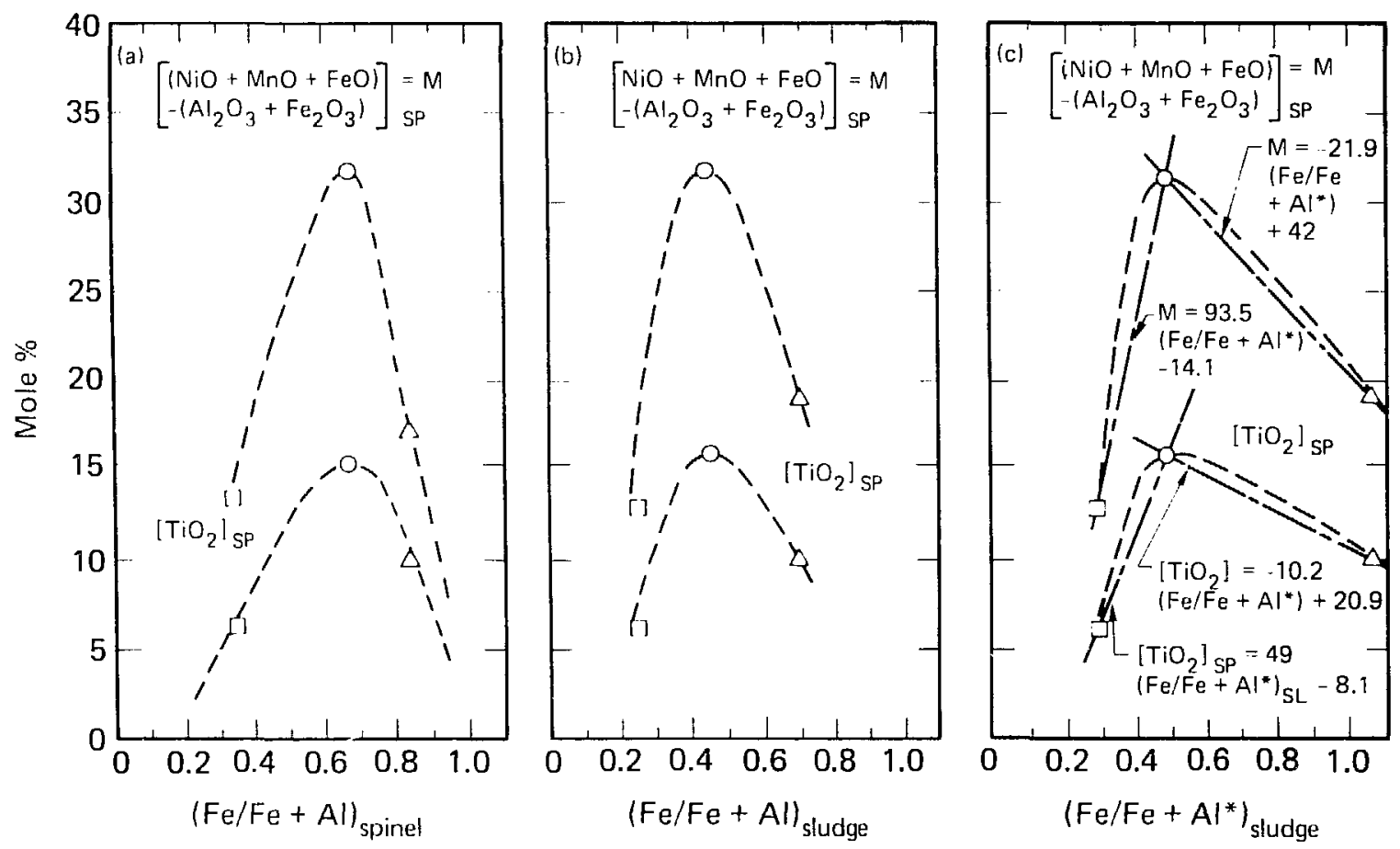

Figure 5. Relationships between various spinel components, and spinel and sludge composition. The sludge compositions are represented as High-Al ( $\square$ ), composite $(0)$, and High-Fe $(\Delta)$.

a. The parameter $\left[\mathrm{M}=\operatorname{mole}\right.$ o $\left.(\mathrm{NiO}+\mathrm{MnO}+\mathrm{FeO})-\left(\mathrm{Al}_{2} \mathrm{O}_{3}+\mathrm{Fe}_{2} \mathrm{O}_{3}\right)\right]$ and mole $8 \mathrm{TiO}_{2}$ in spinel display similar patterns vs $\mathrm{Fe} / \mathrm{Fe}+\mathrm{Al}$ in spinel (spinel stoichiometry requires spinel $\mathrm{TiO}_{2}$ content be proportional to the excess bivalent over trivalent cations in spinel, which approaches a maximum for the composite composition).

b. Plot of $\mathrm{M}$ and $\mathrm{TiO}_{2}$ in spinel vs $\mathrm{Fe} / \mathrm{Fe}+\mathrm{Al}$ in the sludge mimics that in $5 a$ due to close correspondence between $\mathrm{Fe} / \mathrm{Fe}+\mathrm{Al}$ in spinel and sludge composition. The incorporation of alumina in nepheline has not been considered.

c. Plot of $\mathrm{Fe} / \mathrm{Fe}+\mathrm{Al}^{*}$ vs $\mathrm{M}$ and $\mathrm{TiO}_{2}$ in spinel for the three sludge compositions. $A I^{*}$ is equal to $A l-N a$, which accounts for the $A l$ content of nepheline. $M$ and $\mathrm{TiO}_{2}$ in spinel reach a maximum for the composite composition. Straight lines have been used to interpolate spinel compositions for other sludges, and their equations (Table 5) are used in the ADSYN program. 
$\left.\left[(\mathrm{NiO}+\mathrm{MnO}+\mathrm{FeO})-\mathrm{Al}_{2} \mathrm{O}_{3}+\mathrm{Fe}_{2} \mathrm{O}_{3}\right)_{\mathrm{sp}}\right]$

which is equal to the sum of bivalent transition metal oxides that cannot be accommodated as either aluminate $\left(\mathrm{MAl}_{2} \mathrm{O}_{4}\right)$ or ferrite $\left(\mathrm{MFe}_{2} \mathrm{O}_{4} ; \mathrm{M}=\right.$ bivalent cations). Using the relationship in Fig. 5 and Table 5 , the amcunt of $\mathrm{TiO}_{2}$ needed to form spinels may be calculated as a function of sludge composition. It should be noted that nepheline also requires $\mathrm{Al}_{2} \mathrm{O}_{3}$, as does spinel. In this regard, the amount of $\mathrm{Al}_{2} \mathrm{O}_{3}$ present to form spinel is actually equal to

$\mathrm{Al} *=\mathrm{Al}-\mathrm{Na}$.

This factor should be considered in formulating $\mathrm{Fe} /(\mathrm{Fe}+\mathrm{Al})$ for any sludge. An additional feature of the spinel compositions worthy of note concerns their oxidation state, $\mathrm{Fe}^{3+} / \mathrm{Fe}^{2+}$. A majority of the $\mathrm{Fe}$ in the sample is accommodated in spinel and, therefore, the oxidation state of the $F e$ and spinel reflects that of the entire sample. The oxidation state of the spinel (and of the sample) increases linearly as a function of Fe/Fe + Al* (Fig. 6.) This variation in redox state occurs even though the samples were prepared at the same $O$ fugacity and temperature. Hence, the variation of redox state is solely a function of bulk composition.

Table 5. Linear equations relating spinel and sludge compositions.

\begin{tabular}{|c|c|c|}
\hline & Equation & Region of validity \\
\hline$M^{a}=93.5 \quad F$ & $/\left(F e+A l^{*}\right)^{C}$ sludge -14.1 & $0.2<\mathrm{Fe} /(\mathrm{Fe}+\mathrm{Al} *) \leq 0.50$ \\
\hline$M=-21.9 \quad F$ & $e /\left(\mathrm{Fe}+A I^{*}\right)^{C}$ sludge ${ }^{+42}$ & $0.50<\mathrm{Fe} /\left(\mathrm{Fe}+\mathrm{Al}{ }^{*}\right) \leq 1.10$ \\
\hline $\mathrm{TiO}_{2}^{\mathrm{b}}=-42$ & $\mathrm{Fe} /(\mathrm{Fe}+\mathrm{Al})^{\mathrm{C}}$ sludge $\mathrm{s}^{+8.1}$ & $0.2<\mathrm{Fe} /\left(\mathrm{Fe}+\mathrm{A} 1^{\star}\right) \leq 0.50$ \\
\hline $\mathrm{TiO}_{2}=-10.2$ & $\mathrm{Fe} /(\mathrm{Fe}+\mathrm{Al})^{C}$ sludge +20.9 & $0.50<\mathrm{Fe} /(\mathrm{Fe}+\mathrm{Al} *) \leq 1.10$ \\
\hline
\end{tabular}




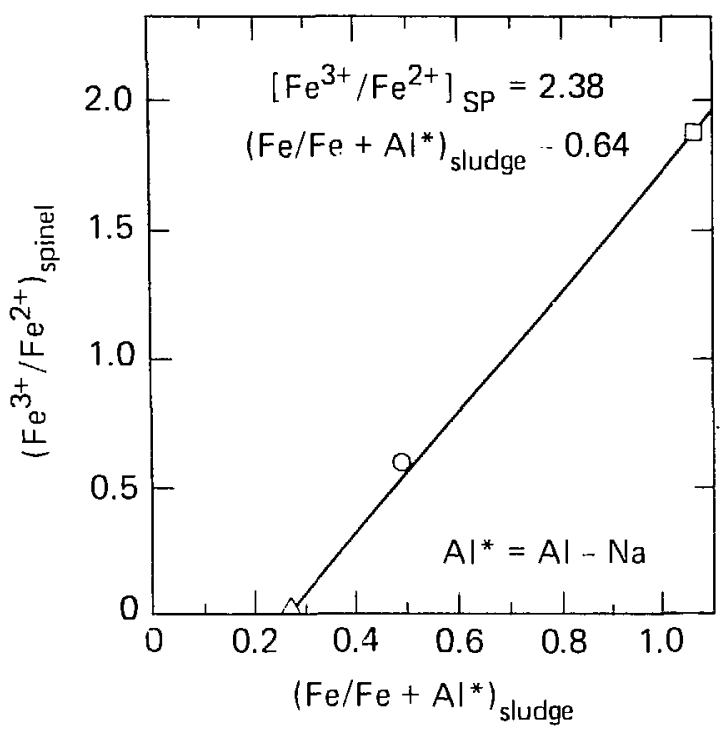

Figure 6. $\mathrm{Fe} / \mathrm{Fe}+\mathrm{Al} *(\mathrm{Al} *=\mathrm{Al}-\mathrm{Na})$ in the sludges bears a linear relationship to the $\mathrm{Fe}^{3+} / \mathrm{Fe}^{2+}$ ratio of the spinel. The $\mathrm{Fe}^{3+} / \mathrm{Fe}^{2+}$ ratio is calculated from spinel stoichiometry. The various sludges are represented by $\mathrm{High}-\mathrm{Fe}$ ( $\square$ ), composite $(0)$, and High-Al $(\Delta)$. The equation of the $\mathrm{fit}$ to these ata is $\left(\mathrm{Fe}^{3+} / \mathrm{Fe}^{2+}\right)_{\mathrm{sp}}=2.38(\mathrm{Fe} / \mathrm{Fe}+\mathrm{Al})_{\text {sludge }}$ -0.54 .

Understanding the correct sample redox conditions as a function of composition is extremely important in determining the manner in which SYNROC-D samples are prepared. For instance, the presently preferred production scenario for SYNROC-D requires a reducing calcine of spray-dried powder followed by hot-pressing in graphite dies. Depending on sample size, these graphite dies may essentially act as inert containers due to rapid densification, low diffusivities and long diffusion paths. In this case, the proper redox state must be impressed on the sample during redox calcination. The relationship displayed in Fig. 6

$\left[\mathrm{Fe}^{3+} / \mathrm{Fe}^{2+}\right]_{\mathrm{sp}}=2.38\left[\mathrm{Fe} /\left(\mathrm{Fe}+\mathrm{Al}^{*}\right)\right]_{\text {sludge }}-0.64$

can be used to determine redox ratios for a large range of sludge compositions. 
The important radionuclide-bearing phases in SYNROC-D are zirconolite, perovskite, and a Cs host phase (either pollucite or hollandite). Our formulations require that the radionuclides, U, Sr, Cs, and the rare earths be immobilized in these phases. Since the incorporation of radionuclides in these phases lepends on their structure and crystal chemistry, important aspects of these parameters are summarized as follows.

The crystal structure of zirconolite has been described by Rossell (1980) and Gatehouse et al. (1981). They confirmed earlier work by Pyatenko and Pudovinka (1964) indicating that zirconolite is related to structures of the defect flourite-type since it is derived by ordering CaF $2-x^{-t y p e ~ s u b u n i t s . ~}$ The monoclinic unit cell is eight times as large as the fluorite subunits and its structure is correctly expressed as $\mathrm{Ca}_{8} \mathrm{Zr}_{8}{ }^{\mathrm{Ti}}{ }_{16}{ }^{\mathrm{O}}{ }_{56} \mathrm{D}_{8}$ ( $\square=0$ vacancy). Rossell (1980) has found that the Ca atoms are coordinated to eight 0 atoms at the corners of a distorted cube. $\mathrm{zr}$ is linked in seven-fold coordination to seven oxygens at the corner of a truncated cube (truncation due to 0 vacancy). Ti occupies three distinct lattice sites. In two of these, $\mathrm{Ti}$ is in octahedral coordination and linked to six o atoms. These 0 atoms are joined at apices to form six-membered and three-membered rings. Ti also resides in a five-fold site, in which the surrounding 0 atoms form a trigonal bipyramid.

Kesson and Ringwood (i981) have investigated the crystal chemistry of zirconolites by analyzing both naturally occurring zirconolites and those produced in synthesis experiments. Their experimental work in the system CaO-TiO ${ }_{2}-\mathrm{ZrO}_{2}$ at $1350^{\circ} \mathrm{C}$ has demonstrated that the zirconolite is quite intolerant to variations in Ca content, allowing only a few at. 8 deficiency. There is, however, considerable variation in the $\mathrm{Zr} / \mathrm{Ti}$ ratio. The general formula can be written as $\mathrm{Cazr}_{\mathrm{x}} \mathrm{Ti}_{3-\mathrm{x}} \mathrm{O}_{7}$, and " $\mathrm{x}$ " varies from $0.9-1.3$ at $1350^{\circ} \mathrm{C}$. Wide variations in $\mathrm{zr} / \mathrm{Ti}$ are also known in naturally occurring zirconolites (Table 6). However, we know of no analyzed zirconolites that contain greater than two Ti atoms per formula unit. It is not uncommon to find $\mathrm{zr}$ in excess of ideal stoichiometry. These patterns indicate that $\mathrm{zr}^{4+}$ may be substituted into $\mathrm{Ti}$ sites and that $\mathrm{Ti}$ may be substituted into $\mathrm{Zr}$ sites. The partitioning of $\mathrm{Ti}$ into $\mathrm{zr}$ sites is less likely, and usually not required by $z$ irconolite stoichiometry. 
Table 6. Analyses of natural zirconolites (after Kesson and Ringwood, 1981).

\begin{tabular}{|c|c|c|c|c|c|c|c|c|c|}
\hline A. Loc. & $\begin{array}{l}\text { Stavern } \\
\text { (brown) }\end{array}$ & $\begin{array}{l}\text { Stavern } \\
\text { (red) }\end{array}$ & Larvik & $\begin{array}{l}\text { Jacu- } \\
\text { piranga }\end{array}$ & Aldan & $\begin{array}{l}\text { Ka iser- } \\
\text { stuhl }\end{array}$ & $\begin{array}{l}\text { Sri } \\
\text { Lanka } \\
\text { (B20392) }\end{array}$ & $\begin{array}{l}\text { Sri } \\
\text { Lanka } \\
(838 n 0)\end{array}$ & $\begin{array}{l}\text { Sri } \\
\text { Lanka } \\
(\mathrm{S} 13-12)\end{array}$ \\
\hline $\mathrm{Nb}_{2} \mathrm{O}_{5}$ & 18.9 & 15.6 & 8.0 & 11.3 & 4.6 & 15.6 & 3.6 & 3.9 & 0.2 \\
\hline $\mathrm{Ta}_{2} \mathrm{O}_{5}$ & 0.4 & 0.2 & 0.7 & 0.2 & 0.1 & 1.2 & -- & - & 0.1 \\
\hline $\mathrm{TiO}_{2}$ & 16.7 & 22.4 & 27.0 & 24.3 & 35.4 & 20.9 & 28.0 & 27.0 & 36.5 \\
\hline $\mathrm{ZrO}_{2}$ & 32.0 & 35.3 & 31.4 & 35.2 & 36.5 & 34.8 & 30.9 & 30.4 & 38.6 \\
\hline $\mathrm{ThO}_{2}$ & 3.7 & 0.6 & 4.1 & 7.4 & 1.2 & 2.9 & 20.5 & 21.8 & 0.9 \\
\hline $\mathrm{UO}_{2}$ & 1.9 & 0.3 & 1.3 & 0.5 & 0.5 & 1.5 & 2.1 & 1.7 & 4.6 \\
\hline $\mathrm{FeO}^{\mathrm{a}}$ & 9.3 & 8.4 & 6.9 & 7.2 & 5.0 & 7.8 & 3.1 & 3.0 & 3.4 \\
\hline Mno & 0.5 & 0.4 & 0.5 & 0.2 & 0.1 & 0.2 & -- & 0.2 & 0.2 \\
\hline MgO & -- & $\cdots$ & -- & 0.4 & -- & 0.3 & 2.4 & 2.5 & 0.6 \\
\hline $\mathrm{CaO}$ & 7.7 & 10.0 & 9.2 & 11.5 & 15.1 & 12.1 & 7.9 & 7.7 & 12.1 \\
\hline $\mathrm{RE}, \mathrm{Y}$ & $f .6$ & 4.8 & 9.3 & 2.5 & 1.9 & 0.9 & -- & -- & -- \\
\hline Total & 97.7 & 97.8 & 98.4 & 100.8 & 99.2 & 98.2 & 98.5 & 97.2 & 96.9 \\
\hline \multicolumn{10}{|c|}{ B. Structural formulas based on 70 atoms. } \\
\hline $\mathrm{Nb}$ & 0.596 & 0.463 & 0.243 & 0.332 & 0.126 & 0.464 & 0.113 & 0.125 & -- \\
\hline $\mathrm{Ta}$ & 0.008 & -- & 0.013 & 0.004 & -- & 0.022 & -- & -- & -- \\
\hline $\mathrm{Ti}$ & 0.876 & 1.105 & 1.366 & 1.186 & 1.611 & 1.034 & 1.456 & 1.433 & 1.718 \\
\hline $2 r$ & 1.089 & 1.129 & 1.030 & 2.114 & 1.077 & 1.117 & 1.042 & 1.047 & 1.178 \\
\hline Th & 0.059 & 0.009 & 0.063 & 0.109 & 0.003 & 0.043 & 0.323 & 0.350 & 0.018 \\
\hline $\mathrm{U}$ & 0.030 & 0.004 & 0.020 & 0.007 & 0.006 & 0.022 & 0.032 & 0.027 & 0.064 \\
\hline $\mathrm{Fe}^{+2}$ & 0.543 & 0.461 & 0.388 & 0.391 & 0.253 & 0.429 & 0.179 & 0.118 & 0.178 \\
\hline $\mathrm{Mn}$ & 0.030 & 0.022 & 0.029 & 0.011 & -- & 0.011 & -- & 0.012 & 0.011 \\
\hline $\mathrm{Mg}$ & -- & -- & -- & 0.039 & -- & 0.029 & 0.247 & 0.263 & 0.056 \\
\hline $\mathrm{Ca}$ & 0.576 & 0.703 & 0.663 & 0.800 & 0.978 & 0.853 & 0.585 & 0.582 & 0.811 \\
\hline $\mathrm{RE}, \quad \mathbf{Y}$ & 0.159 & 0.109 & 0.216 & 0.058 & 0.040 & 0.020 & - & -- & -- \\
\hline Total & 3.963 & 4.004 & 4.030 & 4.051 & 4.094 & 4.045 & 3.978 & 3.957 & 4.028 \\
\hline
\end{tabular}

a All Fe assumed to be Feo.

Kesson and Ringwood (1981) have also conducted experimental investigations of the mechanisms by which $\mathrm{U}^{4+}$ is substituted in zirconolite. They

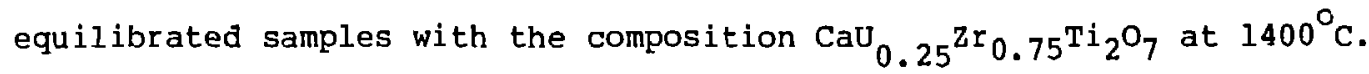
These runs resulted in a U-rich pyrochlore and a relatively U-poor zirconolite (Table 7 ). These results set the $U$ saturation limit in zirconolite at 12.6 wt: (calculated as $\mathrm{UO}_{2}$ ). The zirconolite formula confirms the expected full occupancy of $\mathrm{Ca}$ and $\mathrm{Ti}$ sites. This requires the $\mathrm{U}^{4+}$ (cationic radius $=$ $1.06 \AA$ ) to be accommodated in the $\mathrm{zr}^{4+}$ site (cationic radius $=0.86 \AA$; 
Table 7. Coexisting zirconolite and pyrochlore (after Kesson and Ringwood 1981). ${ }^{a}$

A. Microprobe analyses (wt 8 )

\begin{tabular}{lcc} 
Oxides & Zirconolite & Pyrochlore \\
\hline $\mathrm{TiO}_{2}$ & 42.3 & 37.3 \\
$\mathrm{ZrO}_{2}$ & 29.1 & 18.9 \\
$\mathrm{UO}_{2}$ & 12.6 & 28.0 \\
$\mathrm{CaO}$ & 15.2 & 15.7 \\
Total & 99.2 & 99.9
\end{tabular}

B. Structural formulas based on 7 oxygen atoms.

\begin{tabular}{lcc} 
Cations & Zirconlite & Pyrochlore \\
\hline $\mathrm{Ti}$ & 1.955 & 1.891 \\
$\mathrm{Zr}$ & 0.872 & 0.621 \\
$\mathrm{U}$ & 0.172 & 0.420 \\
$\mathrm{Ca}$ & $\underline{1.001}$ & $\underline{1.134}$ \\
Total & 4.001 & 4.067 \\
\hline
\end{tabular}

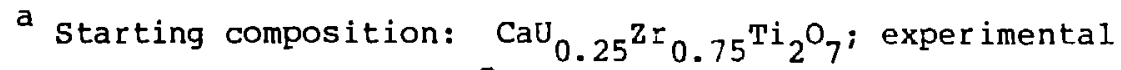
conditions: $5 \mathrm{kbar}, 1400^{\circ} \mathrm{C}, 1 \mathrm{~h}$, Pt capsule.

Whittaker and Muntus, 1970). Hence, one mechanism by which U enters zirconolite is

$\mathrm{u}^{4+} \leftrightarrows \mathrm{Zr}^{4+}$

Reference to the stoichiometry of naturally occurring zirconolites (Table 7) indicates that $\mathrm{Zr}$ per seven $O$ atoms is greater than unity, and the amounts of excess $\mathrm{Zr}, \mathrm{Nb}, \mathrm{Mg}, \mathrm{Fe}$, and $\mathrm{Ti}$ are usually sufficient to $\mathrm{fill}$ all the Ti sites. The Ca site is deficient, however. This suggests that, in more complex: systems, $U$ may enter the Ca site.

Kesson and Ringwood (1981) investigated the partitioning of $U$ into the $\mathrm{Ca}$ site by synthesizing materials along the join $\mathrm{CaZrTi}_{2} \mathrm{O}_{7}-\mathrm{UZrMgTiO}_{7}{ }^{\circ}$ The assumed substitution mechanism is 
$C a^{2+(V I I I)}+\mathrm{Ti}^{2+(V I)} \leftrightarrows \mathrm{u}^{4+(V I I I)}+\mathrm{Mg}^{2+(V I)}$

where $\mathrm{U}$ replaces $\mathrm{Ca}$, and $\mathrm{Mg}$ replaces $\mathrm{Ti}$ to maintain charge balance. The zirconolites produced in the runs contain substantially more $\mathrm{UO}_{2}$ than shown to be capable of entering the $\mathrm{Zr}$ site alone. Hence, some $\mathrm{U}^{4+}$ must be entering the Ca site, and some $\mathrm{Mg}^{2+}$ must be entering the $\mathrm{Ti}$ site, while the remaining portion of $U$ enters the $z r$ site. The sum of these mechanisms allows a maximum of 10 mole $U$ to enter zirconolite.

Both U substitution mechanisms (Eqs. [2] and [3]) should operate in SYNROC-D since $\mathrm{Fe}^{2+}$ can replace $\mathrm{Mg}^{2+}$ in the coupled substitution mechanism, yielding maximum $U$ solubility in zirconolite. The data in Table 4 demonstrate that both substitutions do, in fact, occur in SYNROC-D, but there is no apparent pattern to aid in determining which mechanism predominates. The zirconolites in the High-Fe formulation have completely filled Ca sitos indicating that $\mathrm{U}^{4+}$ must be solely in the $\mathrm{Zr}$ site (low $\mathrm{Fe}^{2+}$, Eq. [2] dominates). The zirconolites in the composite formulation possess full $\mathrm{zr}$ sites (some $\mathrm{Zr}$ may actually be in the $\mathrm{Ti}$ sites) indicating that $\mathrm{U}^{4+}$ could be accommodated totally within the Ca site. In the High-Al formulation, $\mathrm{u}^{4+}$ must be present in both sites.

For the purposes of calculation, both maximum loading and product quality must be considered. Zirconolites are, therefore, never modeled with U concentrations higher than 5 mole $\&$ (the maximum that can be accommodated in the $\mathrm{Zr}$ site). Hence, only U/Zr is allowed to vary. Also, since $\mathrm{UO}_{2}$ is strongly partitioned into zirconolite, it is safe to neglect $\mathrm{UO}_{2}$ incorporation in perovskite (nonstoichiometric substitution $\mathrm{U}^{4+} \leftrightarrows \mathrm{Ca}^{2+}$ ) as long as the zirconolite saturation level is not exceeded.

The rare earth elements in SYNROC are accommodated in a $\mathrm{CaTiO}_{3}$ perovskite. Trivalent lanthanides ( $R E=$ lanthanides) can enter perovskite in a number of ways. Three mechanisms are shown below,

$$
\begin{aligned}
& \mathrm{Na}^{+}+\mathrm{RE}^{3+} \leftrightarrows 2 \mathrm{Ca}^{2+} \\
& \mathrm{RE}^{3+}+\mathrm{Al}^{3+} \stackrel{\mathrm{Ca}}{ }{ }^{2+}+\mathrm{Ti}^{4+} \\
& 2 \mathrm{RE}^{3+}+\mathrm{\square} \\
& \leftrightarrows 3 \mathrm{Ca} .
\end{aligned}
$$

In the first mechanism (Eq. [4a]), a monovalent Na accompanies the trivalent rare earth in substituting for $2 \mathrm{Ca}^{2+}$. In the second mechanism (Eq. [4b]), 
$\mathrm{Al}^{3+}$ enters the six-fold $\mathrm{Ti}$ site, with the rare earth filling the Ca site to maintain charge balance. In the final mecharism (Eq. [4C]), the $R E$ is substituted directly into the $\mathrm{Ca}$ site. To maintain charge balance, a cation vacancy must exist for each two lanthani?e atoms substituted. A recent study by Balachandran and Eror (1981) has shown that single-phase perovskites with the formula La $\mathrm{Sr}_{1-\mathrm{x}_{3}} \mathrm{O}_{3}$ may be synthesized where "x" equals 40 at. 8 . Hence, very little $\mathrm{SrTiO}_{3}$ (or, by analogy, $\mathrm{CaTiO}_{3}$ ) is needed to stabilize the $\mathrm{La}_{2 / 3} \mathrm{D}_{1 / 3} \mathrm{TiO}_{3}$ perovskites.

The SRP sludges contain ample $\mathrm{Na}$ and $\mathrm{Al}$ to accommodate the lanthanides in perovskite via the first two solution mechar:isms (Eqs. [4a] and [4b]). Although there are no known data regarding the maximum concentrations of lanthanides for which these mechanisms are valid, reference to naturally occurring perovskites (Table 8 ) after Haaker and Ewing (1981) indicates they are sufficient to accommodate the lanthanide concentrations in the sludges. However, to maintain a margin of error loverestimation is preferable to underestimation), the additives should be modeled using the third mechanism.

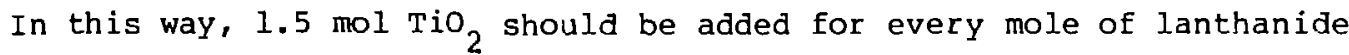
oxide. A further precaution can be added by considering the accommodation of lanthanides in zirconolite. This mechanism is simply

$2 \mathrm{RE}^{3+}+\leftrightarrows \mathrm{Ca}^{2+}+\mathrm{Zr}^{4+}$,

yielding a pyrochlore molecule, $\mathrm{RE}_{2} \mathrm{Ti}_{2} \mathrm{O}_{7}$. For this substitution, 2 mol $\mathrm{TiO}_{2}$ should be added for every mole of lanthanide oxide. Due to the additional margin of safety, our formulations use the pyrochlore calculation.

\section{CS HOST PHASE}

The manner in which the additions for Cs immobilization are calculated depends on the Cs host phase chosen. In some cases, Cs has been treated as a separate stream and immobilized as presynthesized Ba-hollandite. In this case, it can be ignored during the calculation. If $\mathrm{Cs}$ is to be immobilized in situ, it will reside in either pollucite or nepheline. Since the concentration of $\mathrm{Cs}$ in the sludges is small relative to the concentration in pollucite, the modal amount of pollucite necessary would be extremely small $(<10 \mathrm{wt} z)$. In this regard, its presence in syNROC-D assemblages has never 
Table 8. Compositions of natural perovskites (after Haaker and Ewing, 1981 ).

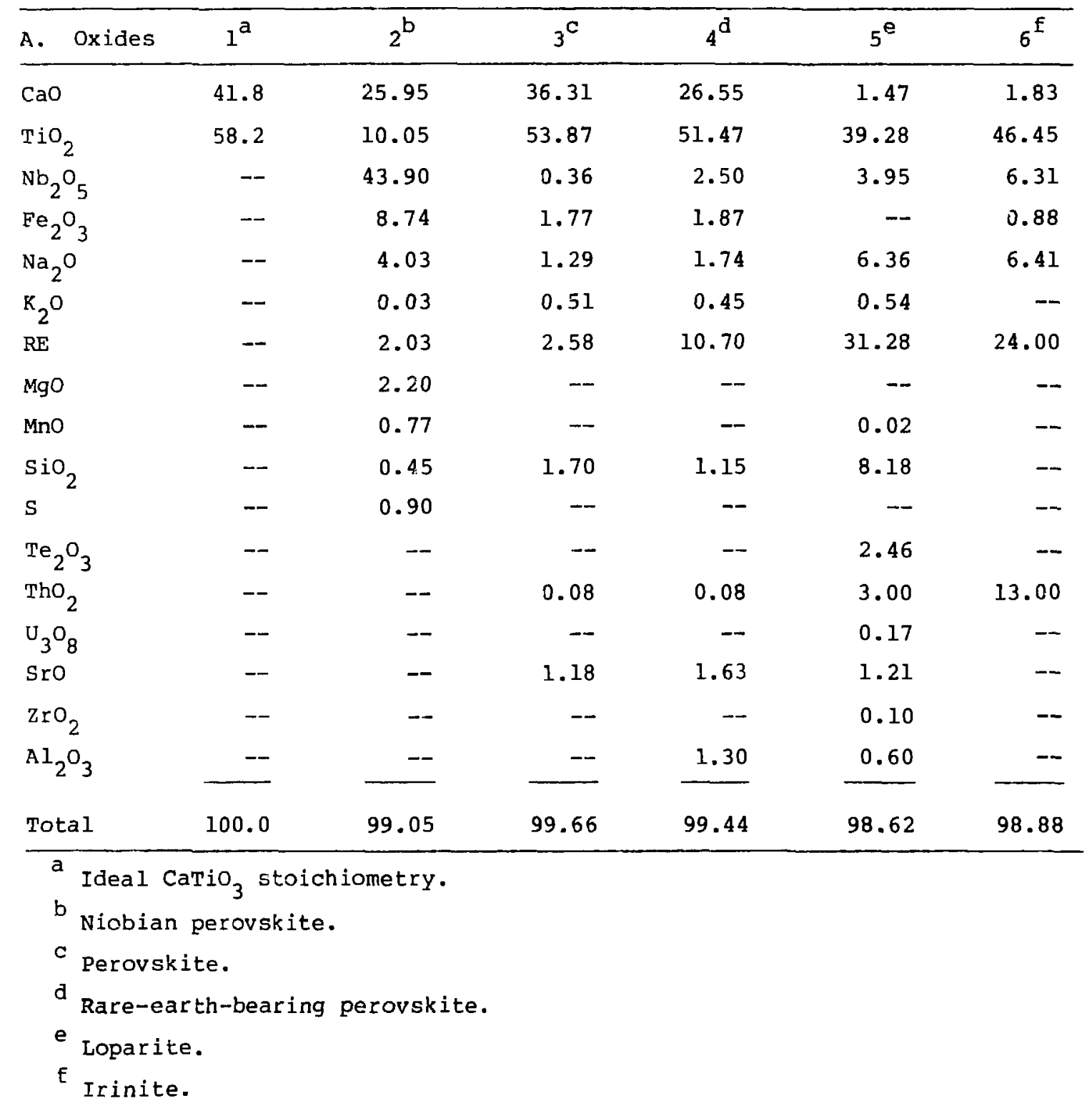


Table 8. (Continued)

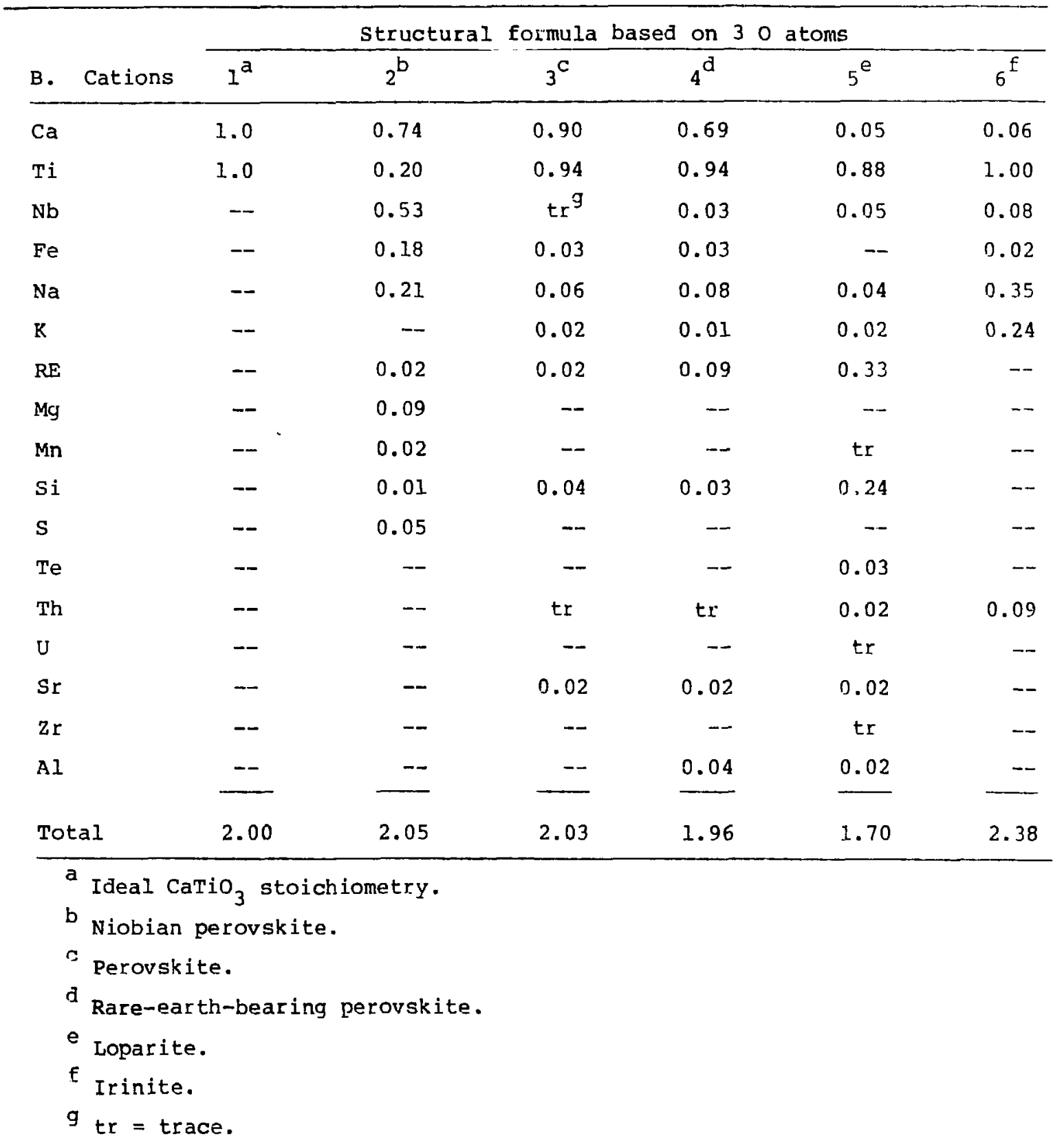


been verified (Ryerson et al., in progress). Due to this ambiguity, we have chosen to let Cs mimic the behavior of $\mathrm{Na}$ immobilized in nepheline.

\section{FORMULATION OF SYNROC-D: SAMPLE CALCULATION}

A sample additive calculation for a typical SRP composite sludge (Table 9) is presented below. For this calculation, mineral compositions similar to those determined by Ringwood et al. 1979 (Table 4c, this report) are employed. The ratio $U /(U+Z r)$ in zirconolite has been set at 0.13 , and $\mathrm{Sr} / \mathrm{Sr}+\mathrm{Ca}$ is set at 0.02 (Table 10). The experimenter could, of course, choose other values for these parameters that would alter waste loading and radionuclide concentrations in the SYNROC phases.

The first step is conversion of the sludge composition to moles of oxide/ $\mathrm{kg}$ calcined sludge. In this conversion, $\mathrm{U}_{3} \mathrm{O}_{8}$ is reduced to $\mathrm{UO}_{2}$, and sulfate ( $\mathrm{Na}_{2} \mathrm{SO}_{4}$ is the actual species) is reduced to sulfide. Also, $\mathrm{Cs}_{2} \mathrm{O}$ is considered to be indistinguishable from $\mathrm{Na}_{2} \mathrm{O}$ in the calculation.

The next step in the calculation is the assignment of sludge and additive constituents to the SYNROC phases described above. This is done by first determining the amount of a given phase required to immobilize a certain sludge constituent. Having done this, the amount of material necessary for phase formation (i.e., nepheline and perovskite) can be calculated. The amount of material necessary for phase formation is then compared to r.he amount present in sludge, and the excess components (or necessary adclitives) can be calculated. Each phase of the procedure just described is illustrated in the following table.

Nepheline is calculated first. The sludge contains 0.88 mol $\mathrm{Na}_{2} \mathrm{O}$ plus $\mathrm{Cs}_{2} \mathrm{O} / \mathrm{kg}$ sludge. Since nepheline is 25 mole $\mathrm{Na}_{2} \mathrm{O}, 3.52 \mathrm{~mol}$ nepheline are required to immobilize $\mathrm{Na}$ and $\mathrm{Cs}$.

\begin{tabular}{llllc} 
Oxides & $\begin{array}{l}\text { Amount necessary } \\
\text { for nepheline } \\
\text { formation } \\
\text { (mol) }\end{array}$ & $\begin{array}{l}\text { Amount } \\
\text { present } \\
\text { in sludge } \\
\text { (mol) }\end{array}$ & $\begin{array}{l}\text { Excess } \\
\text { components } \\
\text { in sludge } \\
\text { (mol) }\end{array}$ & $\begin{array}{l}\text { Necessary } \\
\text { additives } \\
\text { (mol) }\end{array}$ \\
\hline $\mathrm{SiO}_{2}$ & 1.76 & 0.15 & - & 1.61 \\
$\mathrm{Al}_{2} \mathrm{O}_{3}$ & 0.88 & 2.94 & 2.06 & -- \\
$\mathrm{Na}_{2} \mathrm{O}^{*}$ & 0.88 & 0.88 & 0 & -
\end{tabular}


Only part of the $\mathrm{Al}_{2} \mathrm{O}_{3}$ in the sludge is consumed in nepheline formation and $96.8 \mathrm{~g}(1.61 \mathrm{~mol}) \mathrm{SiO}_{2}$ must be added per kilogram of sludge calcined.

The anhydrous sludge contains 0.12 mol of $\mathrm{UO}_{2} / \mathrm{kg}$. This is all assigned to zirconolite (although some is actually accommodated in perovskite). The model zirconolite contains 4.1 mole $\mathrm{UO}_{2}$ requiring 2.93 mol of zirconolite for immobilization.

\begin{tabular}{lcccc} 
Oxides & $\begin{array}{l}\text { Amount necessary } \\
\text { for zirconlite } \\
\text { formation } \\
\text { (mol) }\end{array}$ & $\begin{array}{l}\text { Amount } \\
\text { present } \\
\text { in sludge } \\
\text { (mol) }\end{array}$ & $\begin{array}{l}\text { Excess } \\
\text { components } \\
\text { in sludge } \\
\text { (mol) }\end{array}$ & $\begin{array}{l}\text { Necessary } \\
\text { additives } \\
\text { (mol) }\end{array}$ \\
\hline $\mathrm{TiO}_{2}$ & 1.21 & -- & -- & 1.21 \\
$\mathrm{ZrO}_{2}$ & 0.79 & -- & -- & 0.79 \\
$\mathrm{UO}_{2}$ & 0.12 & 0.12 & 0 & -- \\
$\mathrm{Al}_{2} \mathrm{O}_{3}$ & 0.03 & 2.06 & 2.01 & -- \\
$\mathrm{Fe}_{2} \mathrm{O}_{3}$ & 0.13 & 2.43 & 2.30 & -- \\
$\mathrm{MnO}^{2}$ & 0.04 & 1.22 & 1.18 & -- \\
$\mathrm{NiO}$ & 0.08 & 0.66 & 0.58 & -- \\
$\mathrm{CaO}$ & 0.52 & 0.52 & 0 & \\
$\star \mathrm{Na}$ & & & &
\end{tabular}

This consumes $\mathrm{UO}_{2}, \mathrm{Al}_{2} \mathrm{O}_{3}, \mathrm{Fe}_{2} \mathrm{O}_{3}, \mathrm{MnO}, \mathrm{NiO}$, and $\mathrm{CaC}$ from the sludge and requires the addition of $96.7 \mathrm{~g}\left(1.21 \mathrm{~mol}\right.$ ) $\mathrm{TiO}_{2}$ and $97.3 \mathrm{~g}$ (0.79 mol) $\mathrm{ZrO}_{2}$ to $1 \mathrm{~kg}$ of calcined sludge.

The immobilization of $\mathrm{Sr}$ is achieved by perovskite. The model perovskite contains 1 mole of SrO, and the sludge contains $0.03 \mathrm{~mol}$ Sro/kg. This requires 3 mol of perovskite. Perovskite formation requires the addition of $119.9 \mathrm{~g}$ $\mathrm{TiO}_{2}$ and $82.4 \mathrm{~g} \mathrm{CaO}$ reagent (equivalent oxide) to the sludge.

\begin{tabular}{llllc} 
Oxides & $\begin{array}{l}\text { Amount necessary } \\
\text { for perovskite } \\
\text { formation } \\
\text { (mol) }\end{array}$ & $\begin{array}{l}\text { Amount } \\
\text { present } \\
\text { in sludge } \\
(\mathrm{mol})\end{array}$ & $\begin{array}{l}\text { Excess } \\
\text { components } \\
\text { in sludge } \\
(\mathrm{mol})\end{array}$ & $\begin{array}{l}\text { Necessary } \\
\text { additives } \\
\text { (mol) }\end{array}$ \\
\hline $\mathrm{TiO}_{2}$ & 1.50 & -- & -- & 1.50 \\
$\mathrm{CaO}_{\mathrm{SrO}}$ & 1.47 & 0 & -- & 1.47 \\
$\mathrm{Sr}$ & 0.03 & 0.03 & 0 & --
\end{tabular}


Table 9. Sludge and additive compositions used in sample calculation.

\begin{tabular}{|c|c|c|c|c|c|}
\hline & $1^{a}$ & $2^{b}$ & $3^{c}$ & $4^{d}$ & $5^{e}$ \\
\hline $\mathrm{SiO}_{2}$ & 0.90 & 0.15 & 0.56 & 6.06 & 6.62 \\
\hline $\mathrm{TiO}_{2}$ & -- & -- & -- & 20.12 & 20.12 \\
\hline $\mathrm{ZrO}_{2}$ & -- & -- & -- & 6.09 & 6.09 \\
\hline $\mathrm{U}_{3} \mathrm{O}_{8}$ & 3.50 & 0.12 & 2.19 & -- & 2.19 \\
\hline $\mathrm{Al}_{2} \mathrm{O}_{3}$ & 30.00 & 2.94 & 18.77 & -- & 18.77 \\
\hline $\mathrm{Fe}_{2} \mathrm{O}_{3}$ & 38.80 & 2.43 & 24.28 & -- & 24.28 \\
\hline $\mathrm{MnO}_{2}$ & 10.60 & 1.22 & 6.63 & - & 6.63 \\
\hline Nio & 4.90 & 0.66 & 3.07 & - & 3.07 \\
\hline $30_{4}^{E}$ & 1.00 & 0.10 & 0.63 & -- & 0.63 \\
\hline $\mathrm{CaO}$ & 2.90 & 0.52 & 1.81 & 5.16 & 6.97 \\
\hline $\mathrm{Na}_{2} \mathrm{O}$ & 5.40 & 0.88 & 3.38 & -- & 3.38 \\
\hline $\mathrm{Cs}_{2} \mathrm{O}$ & 0.39 & 0.01 & 0.24 & $-\infty$ & 0.24 \\
\hline $\mathrm{Ce}_{2} \mathrm{O}_{3}$ & 0.78 & 0.023 & 0.49 & -- & 0.49 \\
\hline $\mathrm{Na}_{2} \mathrm{O}_{3}$ & 0.78 & 0.023 & 0.49 & -- & 0.49 \\
\hline Sro & 0.39 & 0.03 & 0.24 & -- & 0.24 \\
\hline Total & 100.34 & - & 62.78 & 37.43 & 100.21 \\
\hline
\end{tabular}

a Typical composite sludge in wto oxide.

b Typical composite sludge, "A", recast as mole of oxide, or metal/1000 $\mathrm{g}$ anyhdrous sludge. $\mathrm{U}_{3} \mathrm{O}_{8}, \mathrm{MnO}_{2}$ ' and $\mathrm{SO}_{4}$ have been reduced to $\mathrm{UO}_{2}, \mathrm{MnO}$, and $\mathrm{S}$, respectively. ${ }^{C}$ wt oxides of sludge in final formulation ( $U$ as $\mathrm{U}_{3} \mathrm{O}_{8}$, $\mathrm{Mn}$ as $\mathrm{MnO}_{2}, \mathrm{~S}$ as $\mathrm{SC}_{4}$ ).

d wtz oxide, additives.

e wto oxide, total bulk composition ( $U$ as $\mathrm{U}_{3} \mathrm{O}_{8}$, Mn as $\mathrm{MnO}_{2}, \mathrm{~S}$ as $\mathrm{SO}_{4}$ ).

$\mathrm{f}^{2}$ sulfur is given as $\mathrm{so}_{4}$ (the actual species is $\mathrm{Na}_{2} \mathrm{SO}_{4}$, and the appropriate amount of $\mathrm{Na}_{2} \mathrm{O}$ is included in the $\mathrm{Na}_{2} \mathrm{O}$ value in column 1 ). 
Table 10. Model mineral compositions for sample calculation (mole fractions).

\begin{tabular}{|c|c|c|c|}
\hline & zirconolite & Perovskite & Nepheline \\
\hline $\mathrm{SiO}_{2}$ & -- & -- & 0.50 \\
\hline $\mathrm{TiO}_{2}$ & 0.414 & 0.500 & -- \\
\hline $\mathrm{ZrO}_{2}$ & 0.270 & -- & -- \\
\hline $\mathrm{UO}_{2}$ & 0.041 & -- & -- \\
\hline $\mathrm{Al}_{2} \mathrm{O}_{3}$ & 0.010 & -- & 0.250 \\
\hline $\mathrm{Fe}_{2} \mathrm{O}_{3}$ & 0.045 & -- & -- \\
\hline $\mathrm{FeO}$ & -- & - & -- \\
\hline MnO & 0.013 & -- & - \\
\hline NiO & 0.028 & -- & -- \\
\hline $\mathrm{CaO}$ & 0.178 & 0.490 & -- \\
\hline $\mathrm{Na}_{2} \mathrm{O}$ & -- & -- & 0.250 \\
\hline Sro & -- & 0.010 & -- \\
\hline $\mathrm{U} / \mathrm{Zr}+\mathrm{u}^{\mathrm{a}}$ & 0.130 & -- & -- \\
\hline $\mathrm{Sr} / \mathrm{Sr}+\mathrm{Ca}^{\mathrm{a}}$ & -- & 0.020 & -- \\
\hline
\end{tabular}

The sulfide content is small $(0.1 \mathrm{~mol})$ and, in our calculation, is assumed to combine with Nio to form Nis. This consumes 0.1 mol of NiO and does not require additives.

At this point in the calculation, excess transition metals are considered in calculating the additives necessary to form spinel. The excess components are illustrated in the table below.

\begin{tabular}{lcc}
$\begin{array}{l}\text { Transition metal } \\
\text { oxides }\left(+\mathrm{Al}_{2} \mathrm{O}_{3}\right)\end{array}$ & $\begin{array}{l}\text { Excess components } \\
\text { in sludge } \\
\text { (mol) }\end{array}$ & $\begin{array}{l}\text { After } \\
\text { reduction } \\
\text { (mol) }\end{array}$ \\
\hline $\begin{array}{l}\mathrm{Al}_{2} \mathrm{O}_{3} \\
\mathrm{Fe}_{2} \mathrm{O}_{3}\end{array}$ & 2.06 & 2.06 \\
$\mathrm{FeO}$ & 2.30 & 1.08 \\
$\mathrm{MnO}$ & -- & 2.45 \\
$\mathrm{NiO}$ & 1.18 & 1.18 \\
$\mathrm{TiO}$ & 0.48 & 0.48 \\
\end{tabular}


From the second column (excess) we calculate $\mathrm{Fe} / \mathrm{Fe}+\mathrm{Al}$ * equal to 0.64 . Using the relationship in Fig. 6 ,

$$
\left(\mathrm{Fe}^{3+} / \mathrm{Fe}^{2+}\right)_{\mathrm{sp}}=2.38(\mathrm{Fe} / \mathrm{Fe}+\mathrm{Al})_{\text {sludge }}-0.64
$$

we obtain an $\mathrm{Fe}^{3+} / \mathrm{Fe}^{2+}$ in the spinel equaling 0.88 . Therefore, the sludge must be reduced to the condition given in the third column. For these calculations, the transition metal oxides are then combined as $\mathrm{Fe}_{3} \mathrm{O}_{4}(1.08 \mathrm{~mol})$, $\mathrm{FeAl}_{2} \mathrm{O}_{4}(1.37 \mathrm{~mol}), \mathrm{MnAl}_{2} \mathrm{O}_{4}(0.69 \mathrm{~mol}), \mathrm{Mn}_{2} \mathrm{TiO}_{4}(0.24 \mathrm{~mol})$, and $\mathrm{Ni}_{2} \mathrm{TiO}_{4}(0.24 \mathrm{~mol})$. This results in a spinel with $\mathrm{TiO}_{2}(6.33$ mole 8$)$. The relation in $\mathrm{Fig}$. $5 \mathrm{c}$,

$$
\left(\mathrm{TiO}_{2}\right)_{\mathrm{sp}}=10.2(\mathrm{Fe} / \mathrm{Fe}+\mathrm{Al})_{\text {sludge }}+20.9
$$

which is valid for $0.50<\mathrm{Fe} /\left(\mathrm{Fe}+\mathrm{Al}^{*}\right)<1.1$ can be used to estimate the $\mathrm{TiO}_{2}$ content of the spinel at 14.4 mole 8 . To maintain a margin for error, the higher value is chosen, which requires the further addition of 1.21 mol or $97.5 \mathrm{~g} \mathrm{TiO}_{2} / \mathrm{kg}$ anhydrous sludge. If ( $\mathrm{Fe} / \mathrm{Fe}+\mathrm{Al}$ ) had been less thar. 0.49 , the relation

$$
\left(\mathrm{TiO}_{2}\right)_{\mathrm{sp}}=49.0\left(\mathrm{Fe} / \mathrm{Fe}+\mathrm{Al}^{*}\right)_{\text {sludge }}-8.1 \text { for } \sim 0.2<\mathrm{Fe} /(\mathrm{Fe}+\mathrm{Al})<0.50
$$

would have been applicable.

The lanthanides add up to $0.046 \mathrm{~mol} / \mathrm{kg}$. These components are cast as a pyrochlore $\left(\mathrm{x}_{2}^{3+} \mathrm{Ti}_{2} \mathrm{O}_{7}\right)$ molecule requiring $0.092 \mathrm{~mol}$ or $7.35 \mathrm{~g}$ of $\mathrm{TiO}_{2}$.

The total additives per kilogram of anhydrous sludge are

\begin{tabular}{lr} 
& \multicolumn{1}{c}{$\mathrm{g}$} \\
$\mathrm{TiO}_{2}$ & 321.5 \\
$\mathrm{ZrO}_{2}$ & 97.3 \\
$\mathrm{CaO}$ & 82.4 \\
$\mathrm{SiO}_{2}$ & 96.8 \\
Total & 598.0
\end{tabular}

This yields a waste loading of $62.6 \mathrm{wt}$ sludge; the final composition is given in Table 9. The expected mineralogy for this formulation is 


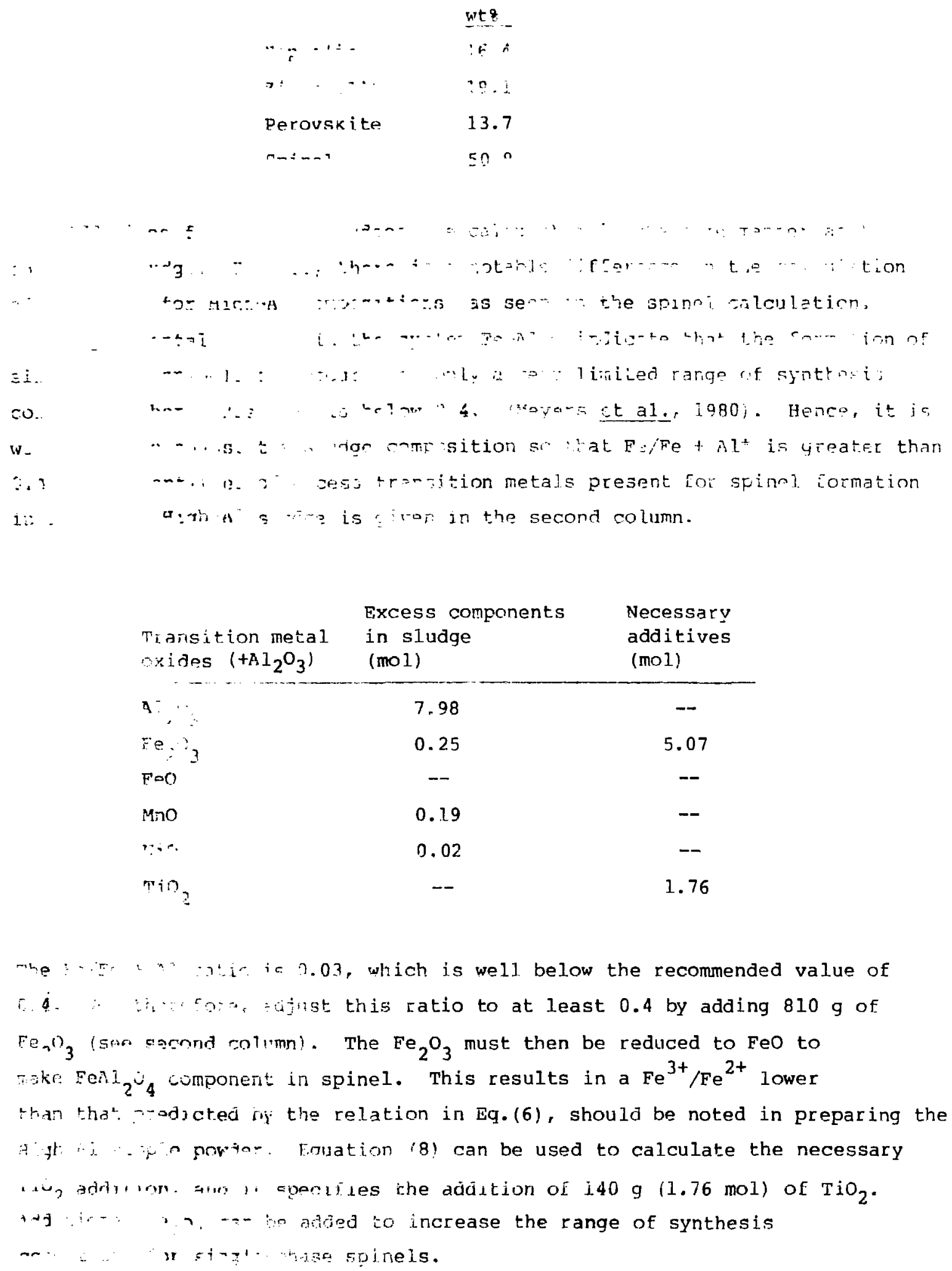


An alternative method employs the addition of Mgo to immobilize $\mathrm{Al}_{2} \mathrm{O}_{3}$ as $\mathrm{MgAl}_{2} \mathrm{O}_{4}$ spinel component. This method requires only $320 \mathrm{~g}$ Mgo for the above composition and has the added advantages of higher waste loading and of requiring no redox control. Ringwood (private communication, 1981) has shown that this alternative produces spinels compatible with the other SYNROC phases. However, at this time, samples produced from this composition have not received the extensive leach testing given the Fe-bearing materials.

\section{CONCLUS IONS}

SYNROC additives to SRP sludge can be calculated so that high waste loading (approximately 60 wt 8 ) and suitably dilute radionuclide concentrations (less than 508 of the saturation value of any radionuclide-bearing phase) are achieved. Compositional variations in SRP sludges are reflected in the composition of the spinels. Compositional trends in spinels $\mathrm{X}_{\mathrm{TiO}}$ and $\mathrm{Fe}^{+3} / \mathrm{Fe}^{+2}$ can be described as the $\mathrm{Fe} / \mathrm{Fe}+\mathrm{Al}$ (atomic) ratio of the sludges. This feature is quite valuable in terms of automated additive calculations (i.e., the ADSYN program [see Appendix A]). To improve these , additive calculations (should such improvement actually be necessary), a more diverse group of sludge compositions must be investigated. This would further our understanding of the relationship between sludge and mineral-phase composition.

\section{ACKNOWLEDGMENTS}

The authors would like to thank Jay Ackerman for his assistance in preparing the ADSYN documentation, as well as Jack Campbell for his comments on the manuscript. 
Balachandran, U. and N. G. Eror (1981), "Solubility of Lanthanum in Strontium Titanate," J. Am. Ceramic. Soc. 63, pp. C75-76.

Gatehouse, B. M., I. E. Grey, R. F. Hill, and H. J. Rossell (1981),

"Zirconolite $\mathrm{CaZr}_{\mathrm{x}} \mathrm{Ti}_{3-\mathrm{x}_{7}}$ : Structure Refinements for Near Endmember

Compositions with $\mathrm{X}=0.85$ and $1.30, "$ submitted to Acta Crystallographica.

Haaker, R. F, and R. C. Ewing (1981), Naturally Occurring Crystalline Phases:

Analogues for Radioactive Waste Forms, Pacific Northwest Laboratory,

Richland, WA, PNL-3505.

Kesson, S. and A. E. Ringwood (1981), Incorporation of Uranium and Rare Earths

into Zirconolite, Lawrence Livermore National Laboratory, Livermore, CA, private communication.

Meyers, C. E., T. O. Mason, W. T. Petuskey, J. W. Halloran, and H. K. Bowen (1980), "Phase Equilibria in the System Fe-Al-0." J. Am. Ceramic. Soc. 63 (11-12), pp. 659-663.

Pyatenko, Y. A. and F. V. Pudovinka (1964), "Lattice Metric of $\mathrm{CaZrTi}_{2} \mathrm{O}_{7}$

Crystals," Krystallographiya 9, pp. 98-100.

Ringwood, A. E. (1981), Lawrence Livermore National Laboratory, Livermore, CA, private communication.

Ringwood, A. E., W. Sinclair, and G. M. McLaughlin (1979), Immobilization of

U. S. Defense Nuclear Wastes Using the SYNROC Process, Lawrence Livermore

National Laboratory, Livermore, CA, UCRL-15147.

Rossell, H. J. (1980), "Zirconolite--a Fluorite-Related superstructure," Nature 278, pp. 219-223.

Ryerson, F. J., G. Smith, and J. Mitchell, Characterization of SYNROC-D,

Lawrence Livermore National Laboratory, Livermore, CA (i.n progress). Stone, J. A., S. T. Goforth, Jr., and P. K. Smith (1979), Preliminary

Evaluation of Alternative Forms for the Immobilization of Savannah River

Plant High-Level Waste, DuPont Savannah River Laboratory, Aiken, SC, BP-1545. Whittaker, E. J. W. and R. Muntus (1970), "Ionic Radii for Use in

Geochemistry," Acta Geochimica et Cosmochimica 34, pp. 945-956. 
APPENDIX A

\section{ADSYN: A COMPUTER PROGRAM FOR CALCULATION OF SYNROC ADDITIVES}

ADSYN is an interactive FORTRAN program (see microfiche at the end of this report) that calculates the amounts of SYNROC additives and resulting nominal mineral compositions for a given input sludge composition. The program is now run on a Hewlett Packard Model HP 1000 computer system.

Here is a simplified flow sheet for ADSYN operation:

1. User input of sludge composition and desired solid solution limits for $\mathrm{Sr}$ and $\mathrm{U}$.

2. Calculation of additives necessary to approximate DP1545 compositions.

3. Calculation of $\mathrm{Cs}$ and $\mathrm{Na}$ immobilization in nepheline.

4. Calculation of $U$ immobilization in zirconolite.

5. Calculation of Sr immobilization in perovskite.

6. Calculation of $S$ immobilization in nickel sulfide.

7. Calculation of lanthanides (Ce, Nd) as a "pyrochlore" (RETi ${ }_{2} \mathrm{O}_{7}$; rare earths are distributed between perovskite and zirconolite).

8. Calculation of $\mathrm{Mn}, \mathrm{Fe}, \mathrm{Ni}$, and $\mathrm{Al}$ as spinel.

9. Output of quantities of reagent additives, equivalent oxide composition, nominal mineral compositions (as weight proportions).

Input can be entered by the user from an HP 1000 terminal or as a data file. The user can choose to: 1) adjust starting composition to a DP1545 reference composition (stone et al. 1979), or 2) input his own reference composition. The second option is useful when the user wishes to examine the effects of varying quantities of individual components.

The required input is

1. Sludge composition (wt 8 ).

2. Sludge weight in grams.

3. Reference composition type, i.e., DP1545 High-Fe, High-Al, composite or user input reference.

4. Whether or not all components are adjusted to DP1545 reference or just $\mathrm{Fe}$ and $\mathrm{Al}$.

5. Whether $\mathrm{Cs}$ is included in the sludge.

6. Desired $\mathrm{Sr} / \mathrm{Sr}+\mathrm{Ca}$ ratio in perovskite. 
7. Desired $U / U+z r$ ratio in zirconolite.

8. Desired percentage safety margin (over tailoring of $\mathrm{TiO}_{2}$ ).

If the user wishes to input his own reference composition, he must also input

9. DP1545 sludge type closest to the composition.

10. Sludge composition.

A typical sequence of input/output at a terminal is shown in Fig. A-l.

It should be noted that, although the program asks for wet sludge composition and weight, the user may input dry compositions as long as consistency is maintained.

A user may want to repeat a number of tests with the same starting sludge composition or with only minor changes. With this in mind, the option is available for data file input. To run the program, all the user need do is specify the data file input option and give the name of the existing data file. The required data file format setup and a sample are shown in Fig. A-2.

To cut down on the number of user input steps in the interactive input, default "actual additives" (reagents) are assumed. If the user wishes to change the "actual additives," he must use the data file input option (Fig. A-2). A sample program output is shown in Fig. A-3.

The program outputs:

1. The spinel $\mathrm{Fe}^{+3} / \mathrm{Fe}^{+2}$ ratio and whether or not it was adjusted from the ratio equation: $\mathrm{Fe}^{+3} / \mathrm{Fe}^{+2}=2.338 *[\mathrm{Fe} /(\mathrm{Fe}+\mathrm{Al})]-0.64$.

2. Sludge type.

3. Mineral compositions.

4. The $\mathrm{TiO}_{2}$ safety factor, $\mathrm{Sr} /(\mathrm{Sr}+\mathrm{Ca})$ and $\mathrm{U} /(\mathrm{U}+\mathrm{Zr})$ ratios (these three are user inputs).

5. A composition table of:

a. Original sludge.

b. DP1545 (or reference) composition.

c. Additions to get to DP1545.

d. Working composition.

e. SYNROC additions.

f. Total (SYNROC + DP1545) additions.

6. A table of actual additives/100 $\mathrm{g}$ sludge and per user input of total sludge weight (the example shows $1000 \mathrm{~g}$ ).

7. A table of anhydrous composition for original sludge, additives, and total. 
WAITING FOR INPUT

:ADSYN - Type the name of the code to start.

DO YOU WISH TO INPUT DATA FROM THE TERMINAL OR FROM A DATA FILE?NOTE:

IF YOU WISH TO CHANGE THE DEFAULT REAGENTS TO BE ADDED, YOU MUST USE DATA FILE INPUT

INPUT 1 FOR TERMINAL OR 2 FOR A DATA FILE

1

Specifies interactive input.

INPUT SLUDGE COMPOSITION - WT\% OF TOTAL (WET) SLUDGE

\begin{tabular}{|c|c|c|}
\hline $\mathrm{Fe} 203$ & $=$ & 44.3 \\
\hline AL203 & & $\overline{31.7}$ \\
\hline $\mathrm{MnO2}$ & $=$ & 12.3 \\
\hline U308 & $=$ & $\frac{1}{0}$ \\
\hline $\mathrm{CaO}$ & $=$ & $\overline{1} .7$ \\
\hline NiO & $=$ & $\overline{4.8}$ \\
\hline SiO2 & $=$ & $\overline{1.2}$ \\
\hline $\mathrm{Na} 20$ & $=$ & 1.4 \\
\hline $\mathrm{Na} 23 \mathrm{SO} 4$ & $=$ & 1.3 \\
\hline SrO & $=$ & 0 \\
\hline $\mathrm{Md} 203$ & $=$ & $\overline{0}$ \\
\hline Ce203 & $=$ & $\underline{0}$ \\
\hline Cs2O & $=$ & $\bar{\pi}$ \\
\hline
\end{tabular}

INPUT TOTAL WET SLUDGE WEIGHT IN GRAMS 8596.

INPUT DESIRED DP1545 COMPOSITION:

(1) NO AL REMOVAL, HIGH FE

(2) NO AL REMOVAL, COMPOSITE

(3) NO AL REMOVAL, HIGH AL

(4) OTHER - TO BE ENTERED AT TERMINAL

INPUT $1,2,3$, OR 4

$4 \longleftarrow$ Specifies operator input of DP1545 composition.

INPUT CLOSEST DP1545 TO DESIRED COMPOSITION FOR USE IN CALCULATING MINERAL COMPS. :

$$
\begin{aligned}
& 1--H I \text { FE } \\
& 2-- \text { COMPOSITE } \\
& 3--H I \text { AL }
\end{aligned}
$$

$\underline{2}$

SHOULD ALL COMPOUNDS BE ADJUSTED TO DP1545 OR JUST AL203 AND FE203? ENTER 1 FOR ALL AND 2 FOR FE203 \& AL203

$\underline{1}$

SHOULD DP1545 INCLUDE Cs20?

INPUT 1 FOR YES AND 2 FOR NO 1

INPUT DESIRED $\mathrm{Sr} /(\mathrm{S} r+\mathrm{Ca})$ RATI $\overline{0} .027$

INPUT DESIRED $U /(\mathrm{U}+\mathrm{Zr} r)$ RATIO $\underline{.13}$

Figure A-1. Example of running ADSvN code with interactive data input. 
INPUT DESIRED SAFETY MARGIN FOR TIO2. EX:

INPUT 1.0 IF NO ADDITIONAL TIO2 ABOVE THAT CALCULATED SHOULD BE ADDED.

INPUT 1.1 IF 10\% ADDITIONAL TIO2 SHOULD BE ADDED FOR SAFETY.

$\underline{1 .}$

INPUT DESIRED STARTING COMPOSITION OTHER THAN DP1545

$\mathrm{Fe} 2 \mathrm{O3}=44.3$

$\mathrm{AL203}=\overline{34.65}$

$\mathrm{MnO2}=\frac{\overline{12.19}}{4.0}$

$\mathrm{U} 308=\frac{1.0}{3.3}$

$\mathrm{CaO}=\overline{3.3}$

$\mathrm{NiO}=\frac{3.8}{4.0}$

$\mathrm{SiO2}=\frac{\overline{1.04}}{6.23}$

$\mathrm{Na} 2 \mathrm{O}=\frac{1.04}{6.23}$

$\mathrm{Na23SO4}=\frac{6.23}{1.14}$

Sro $=\frac{.49}{.98}$

Md203 $=\frac{.99}{.98}$

$\mathrm{Ce} 203=\frac{.98}{.98}$

$\mathrm{Cs} 20=\underline{.49}$

The desired composition was input to adjust the DP1545 composition so that no NiO would be needed.

The results of the calculation are printed into hardcopy.

The output follows (Fig. 2).

Figure A-1. (continued) 
Row 1- Starting sludge composition, wt\%:

$\mathrm{Fe} 203, \mathrm{~A} 1203, \mathrm{MnO2}, \mathrm{U} 308, \mathrm{CaO}, \mathrm{Ni0}, \mathrm{Si} 02, \mathrm{Na} 20, \mathrm{Na} 2 \mathrm{SO} 4, \mathrm{SrO}, \mathrm{Nd} 203, \mathrm{Ce} 203$, Cs20

Row 2- Total sludge weight, grams

Row 3- Desired reference composition (first three are DP1545):

$$
\text { 1- } \mathrm{HiFe} 2 \text { - Composite 3- Hi Al 4-Other (see Row }
$$

4)

Row 4- Other reference composition. This is only used if a 4 is entered in Row 3, but numbers (even if $0^{\prime} \mathrm{s}$ ) must be entered as space holders

Row 5- Closest DP1545 to reference composition:

$$
\text { 1 - } \mathrm{HiFe} 2 \text { - Composite 3- } \mathrm{Hi} \mathrm{Al}
$$

Row 6- Reference adjustment to starting sludge:

1 - all compounds adjusted 2 - on 1 y Al203 and Fe203 adjusted

Row 7- Should Cs20 be included?:

$$
1 \text { - yes } 2 \text { - no }
$$

Row 8- $\mathrm{Sr} /(\mathrm{Sr}+\mathrm{Cs})$ ratio in perovskite

Row 9- $U /(U+Z r)$ ratio in zirconolite

Row 10 - Ti02 safety margin, see Fig. A-1

Rows 11-25 - Actual additives and formula weights. Each a iditive name and name must be 16 , and only 16 , characters $1 .: 1 \mathrm{~g}$ (incl. spaces and punctuation). The additive name if followed by the formula weight. The additives must be input in the following order?

Row 11 - Fe, Row 12 - A1, Row 13 - Mn, Row 14 - U, Row 15 - $\mathrm{Ca}$, Row 16 - Ni, Row 17 - $\mathrm{Si}$, Row 18 - Na20, Row 19 - Na2S04, Row 20 - Sr, Row 21 - Nd, Row 22 - Ce, Row 23 - Cs, Row 24 - Ti, Row 25 - Zr

Row 26 - Additive multiplication factors. This is the number of moles of additive that must be added to get 1 mole of principal component. For example: To get 1 mole of Fe203, 2 moles of $\mathrm{Fe}$ (N03) 39 H2O must be added. Therefore, the multiplication factor is 2.0. Multiplication factors must be entered on one row and separated by commas or spaces, in the same order as the additives are entered in Rows 11-25.

Figure A-2. Data file input format with example. 


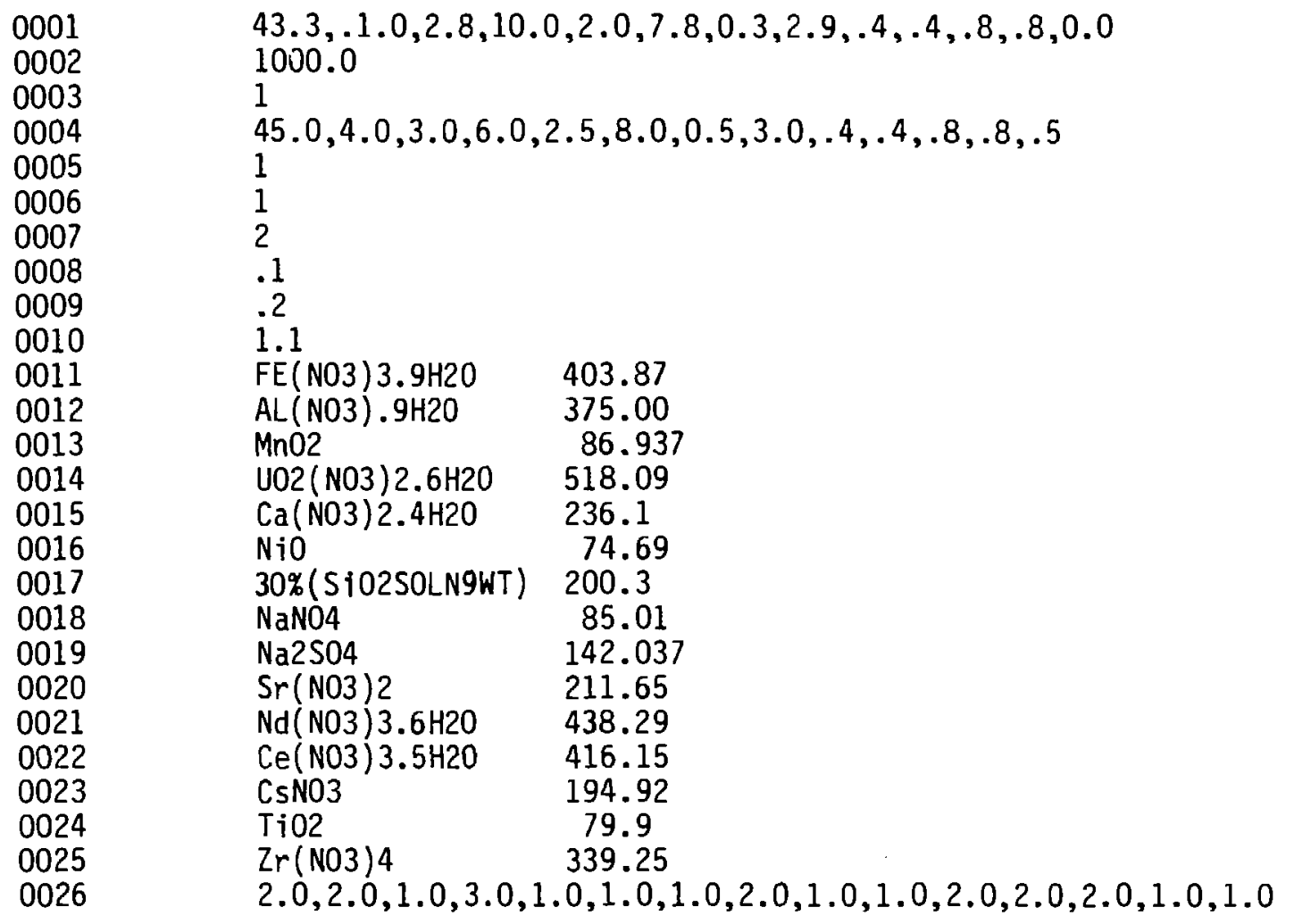

Figure A-2. (continued) 
THE SPINEL FE+3/+2 RATIO IS 1.42

IT DID NOT NEEL ADJUSITENT

HIGH FE SLUDGE

MINERAL COMPOSITIONS

NEPHELINE

MOLES

M. FRN. WT. FRN.

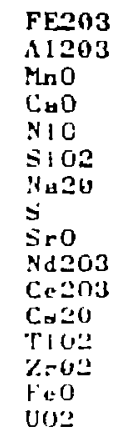

0.00
.359
0.00
0.00
0.00
.423
.210
0.00
0.00
0.00
0.00
0.00
0.00
0.00
0.09
0.00

ZIRCONOLITE

MOLES

M. FRN.

SULF I DE

MOLES

M. FHN.

HT . FIN

0.00
0.00
0.00
0.00
.345
0.00
0.00
0.650
0.00
0.00
0.00
0.00
0.000
0.600
0.50
0.00

0.061

0.00

$\begin{array}{ll}.033 & .047 \\ .003 & .004 \\ .017 & .024 \\ .0713 & .251 \\ 0.000 & 0.00 \\ 0.000 & 0.00 \\ 0.000 & 0.00 \\ 0.009 & 0.00 \\ 0.000 & 0.00 \\ 0.000 & 0.00 \\ 0.000 & 0.00 \\ 0.000 & 0.00 \\ .299 & .422 \\ .143 & .202 \\ 0.000 & 0.00 \\ .036 & .051\end{array}$

\section{LANTHANI DE}

MOLES

M. FRN

\subsection{9}

0.000

0.000

0.1000

0.060

0.000

0.00

0.060

,

.002

.

.610
.0615

(9.

0. $0(1)$

0.00
0.00
0.00
0.001
0.00
0.001
0.001
0.09
0.001
.160
0.169
0.010
.607
0.00
0.00
0.00

PETOVSKITE

WT. FRN .

.078
.004
.022
.140
0.06
0.00
0.019
0.00
0.00
0.00
0.00
0.60
.350
.256
0.00
.142

.142

HT . FIN.

0.00

0.00

0.06

0.00

4). 0 (1)

0.06

0.00

0.00

0.09

.3:3is

.313
0.00

a. 325
MOLES

M. FRN.

WT. FRN.

$\begin{array}{ll}0.000 & 0.00 \\ 0.000 & 0.00 \\ 0.000 & 0.00 \\ .035 & .450 \\ 0.000 & 0.00 \\ 0.000 & 0.00 \\ 0.000 & 0.00 \\ 0.000 & 0.00 \\ .004 & .050 \\ 0.000 & 0.00 \\ 0.000 & 0.00 \\ 0.000 & 0.00 \\ .059 & .500 \\ 0.000 & 0.00 \\ 0.000 & 0.00 \\ 0.000 & 0.00\end{array}$

0.00

0.60

$\begin{array}{ll}0.00 & 0.60 \\ .450 & .354\end{array}$

0.000 .00

$0.00 \quad 0.00$

$050 \quad 0.60$

.674

0.06

0.00

5684

0.60

(1).

\section{SPINEL}

MOLES M. FRN. WT.FIN.

\begin{tabular}{|c|c|c|}
\hline .139 & .247 & .403 \\
\hline .043 & .076 & . \\
\hline .016 & .029 & . 11206 \\
\hline 0.000 & 0.00 & 0.001 \\
\hline .102 & $.1 B 0$ & $.1: 37$ \\
\hline 0.000 & 0.00 & $0.110)$ \\
\hline 0.0001 & 0.00 & 0.001 \\
\hline 0.050 & 0.100 & 0.00 \\
\hline $11.00(9)$ & (4). 00 & (1.,06) \\
\hline 0.096 & 0.00 & (6.50 \\
\hline 0.000 & $0.1: 0$ & $0 .(1)$ \\
\hline 0.0001 & 0.00 & 0.1111 \\
\hline . otsis & 1121 & $.09,1$ \\
\hline 0.000 & 0.001 & 0.610 \\
\hline .197 & $.34 \%$ & .250 \\
\hline 0.000 & 0.00 & 0.64 \\
\hline
\end{tabular}

Figure A-3. Sample output. 


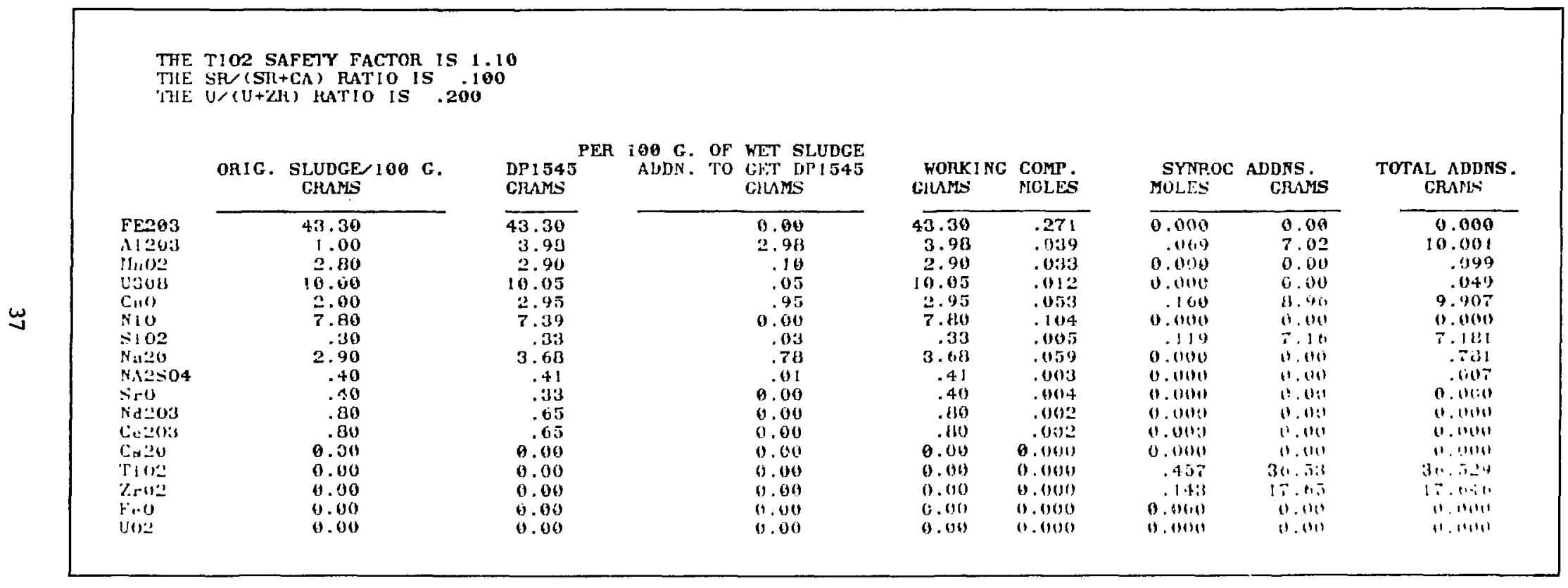

Figure A-3. (continued) 


\begin{tabular}{|c|c|c|c|c|c|}
\hline & \multirow[b]{2}{*}{ PER 100} & \multicolumn{3}{|c|}{$\begin{array}{l}\text { ADDITIONS: SYNROC + DP1545 } \\
\text { ACTUAL ALDITIVES - GRAMS }\end{array}$} & $90 \mathrm{C}$ KET \\
\hline & & G WE:T SLUDGE & PER & 1000.00 & SLUDGE \\
\hline FE(NO3)3.9H2O & & 0.00 & & & 0.00 \\
\hline AL(NO3) $3.9 \mathrm{JJ} 20$ & & 73.57 & & & 735.66 \\
\hline $\mathrm{MnO2}$ & & .10 & & & .99 \\
\hline vo2 (NO3)2.6H20 & & .09 & & & .91 \\
\hline $\mathrm{Ca}(\mathrm{NOS}) 2.4 \mathrm{H}=0$ & & 41.71 & & & 417.11 \\
\hline NiO & & 0.00 & & & 0.00 \\
\hline $36 \%$ StO SOLN (WT) & & 23.94 & & & 239.40 \\
\hline $\mathrm{N}_{4} \mathrm{NOO}$ & & 2.14 & & & 21.42 \\
\hline $\mathrm{Na} 2 \mathrm{SO4}$ & & .01 & & & .07 \\
\hline$S r(N 03) 2$ & & 0.00 & & & 0.00 \\
\hline $\mathrm{Nd}(\mathrm{NO} 3) 3.6 \mathrm{H} 2 \mathrm{O}$ & & 0.00 & & & 0.00 \\
\hline Ce(Nio3) $3.51 i 20$ & & 0.00 & & & 0.00 \\
\hline ConOS & & 0.00 & & & 0.00 \\
\hline Till: & & 36.53 & & & 365.29 \\
\hline$Z \Gamma(N 03) \div$ & & 43.58 & & & 485.83 \\
\hline
\end{tabular}

Figure A-3. (continued) 


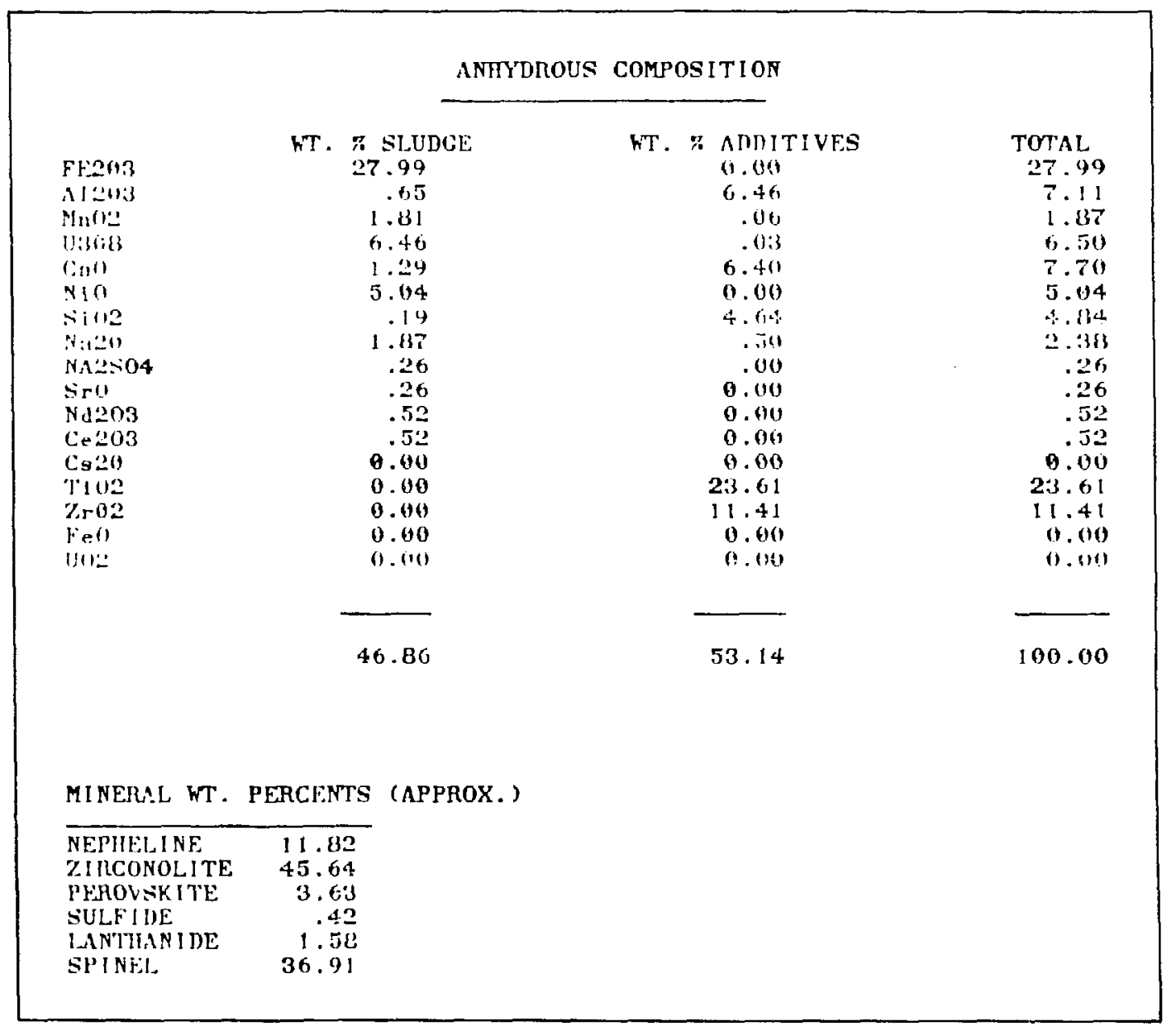

Figure A-3. (continued) 